\title{
Human Health Risk Assessment of Trace Elements in Tap Water and the Factors Influencing Its Value
}

\author{
Katarzyna Wątor $^{1}\left(\mathbb{D}\right.$, Piotr Rusiniak ${ }^{1}\left(\mathbb{D}\right.$, Agnieszka Martyna ${ }^{2}$, Ewa Kmiecik ${ }^{1}$ (D) and Adam Postawa ${ }^{1, *(\mathbb{D})}$ \\ 1 Department of Hydrogeology and Engineering Geology, AGH University of Science and Technology, \\ 30-059 Kraków, Poland; katarzyna.wator@agh.edu.pl (K.W.); piotr.rusiniak@agh.edu.pl (P.R.); \\ ewa.kmiecik@agh.edu.pl (E.K.) \\ 2 Forensic Chemistry Research Group, Institute of Chemistry, Faculty of Science and Technology, University of \\ Silesia in Katowice, 40-006 Katowice, Poland; agnieszka.martyna@us.edu.pl \\ * Correspondence: postawa@agh.edu.pl; Tel.: + 48-12-617-2398
}

Citation: Wator, K.; Rusiniak, P.; Martyna, A.; Kmiecik, E.; Postawa, A. Human Health Risk Assessment of Trace Elements in Tap Water and the Factors Influencing Its Value. Minerals 2021, 11, 1291. https://doi.org/ $10.3390 / \min 11111291$

Academic Editor: Alakendra

N. Roychoudhury

Received: 13 October 2021

Accepted: 15 November 2021

Published: 20 November 2021

Publisher's Note: MDPI stays neutral with regard to jurisdictional claims in published maps and institutional affiliations.

Copyright: (c) 2021 by the authors. Licensee MDPI, Basel, Switzerland. This article is an open access article distributed under the terms and conditions of the Creative Commons Attribution (CC BY) license (https:// creativecommons.org/licenses/by/ $4.0 /)$.

\begin{abstract}
Background: The influence of tap water fittings construction and internal pipe-work on the release of heavy metals was investigated. (2) Methods: A statistical approach was applied for the examination of the chemistry of tap water in five different cities in southern Poland. In total, 500 samples were collected (from 100 to 101 samples in each city). The sampling protocol included information on the construction of the water supply network and the physicochemical parameters of measured tap water. (3) Results: The statistical analysis allowed to extract the crucial factors that affect the concentrations of trace elements in tap water. Age of connection, age of tap, age of pipe-work as well as material of connection, material of pipe-work and material of appliance reveal the most significant variability of concentrations observed for $\mathrm{As}, \mathrm{Al}, \mathrm{Cd}, \mathrm{Cu}, \mathrm{Fe}, \mathrm{Mn}, \mathrm{Pb}$, and $\mathrm{Zn}$. Calculated cancer risks (CRs) decrease with the following order of analysed elements $\mathrm{Ni}>\mathrm{Cd}>\mathrm{Cr}>$ $\mathrm{As}=\mathrm{Pb}$ and can be associated with the factors that affect the appearance of such elements in tap water. The hazard index (HI) was evaluated as negligible in $59.1 \%$ of the sampling points and low in $40.1 \%$ for adults. For children, a high risk was observed in $0.2 \%$, medium in $9.0 \%$, negligible in $0.4 \%$, and low for the rest of the analysed samples.
\end{abstract}

Keywords: trace elements; aquatic environment; tap water; risk assessment; hazard Index; multivariate statistics

\section{Introduction}

In recent years, great importance has been placed on the protection of human health. Increased attention is paid to toxic components of the environment, which occur naturally (e.g., metals, metalloids) or are introduced artificially by humans (e.g., pesticides), and which harm human health. Risk analysis deals with the issues of the harmful effects of various substances on human health. It is an issue more commonly discussed in scientific articles that present risk associated with, e.g., acceptable daily intake (ADI), lowest no observed adverse effect level (NOAEL), drinking water equivalent level (DWEL), cancerogenic risk (CR), non-cancerogenic risk (NCR), and related to the introduction of harmful substances by different routes into the human body, e.g., ingestion, dermal contact, inhalation [1-13]. The total risk related to the substances considered is therefore expressed in the form of the hazard quotient (HQ) or hazard index (HI), which, depending on their value, indicate low or high risk.

In every chemical research on natural water (ground-, surface, geothermal) including water intended for human consumption, it must be ensured that the obtained results are reliable. This requirement cannot be fulfilled without properly conducting quality control of the research and collecting representative samples in accordance with international standards and norm series. 
Water quality tests are carried out routinely, but there is a lack of a harmonized water samples collection protocol from the water supply network despite the clear requirements of the directive of the European Council 98/83/EC of 3 November 1998, the Regulation of the Minister of Health of 7 December 2017 [14-18] and the revised Directive of the European Parliament and of the Council [19], all on the scope of water intended for human consumption. Therefore, the results obtained from research conducted at the same place but with the application of different protocols during sampling collection can differ significantly $[20,21]$.

One of the main problems is to accept only one, universal method of water samples collection which ensures obtaining reliable results from the research conducted in points of drawing, treating, distribution and tap of the end-user. It also implies a difficulty in the application of an integrated quality assurance/quality control programme (QA/QC) and estimation of results uncertainty related to all stages of the research. The recommendations considering sampling of water intended for drinking purposes were described in a standard ISO 5667-5 [22] Water quality-Sampling-Part 5: Guidance on sampling of drinking water from treatment works and piped distribution systems, but no harmonized methodology or volume of tap water that should be collected is pointed out [23]. In some worldwide research, samples of volumes 50, 100 or $250 \mathrm{~mL}$ were collected [24,25]. In compliance with the guidelines there, samples for assessment of the quality of drinking water should be collected from different points in the water supply network [10]. Special attention should be paid to the elements placed directly before the next stage of the water treatment process. The International Water Association [26-28] recommends conducting water quality research on the whole way of water flow-from the source to the end-user's tap. Regardless of the sampling methodology used, the most important is to ensure the good quality of water for the end-user. Therefore, it is necessary to identify the factors that can affect the results of drinking water analyses. This information is necessary to develop one universal sampling protocol which will consider all important variables and sources of variation in the water composition.

The quality of tap water can change over a time since the processes of secondary pollution in water network installation systems (WNISs) take place constantly. The WNISs kind and intensity are conditioned by the type of material used for its construction, network project, implementations and usage conditions. The deterioration of water quality can be due to changes in physical parameters (colour, turbidity), chemical parameters (undesirable increase in heavy metals concentrations), and bacteriological parameters. The effect of these changes may be the dissatisfaction of end-users with the quality of tap water or the incapacity of water for human consumption [29].

One of the most important issues related to water quality research is the influence of water stagnation time in the water network and therefore the time of its contact with internal elements of installation, and appliance on a water chemical composition. Errors arising from the determination of the concentration levels of heavy metals in water intended for human consumption are related to the insufficient flush of installation before collection of water samples [20,21,30-32].

All the above-mentioned factors can influence the quality of water mainly by changes in concentrations of some metals and metalloids and, therefore, pose a risk to human health. The non-carcinogenic and carcinogenic effect of drinking water on human health is usually calculated for raw water or based on samples collected directly from the waterworks [3,5,7,12,13,33-41]. Only a few studies consider tap water samples [42,43].

Chemometric methods are successfully implemented for the assessment of groundwater [44,45] and surface water quality [46-49], analysis of pollutants in wastewater [50] and groundwater [51], characterisation of groundwater chemistry [52,53], contamination of aquifers [54], assessment of spatial variability of curative water [55], or identification of the correlations between different components of water intended for human consumption and tap water [21,32,56-63]. 
The aim of the presented research is to indicate the human health risk arising from the consumption of water containing elevated concentrations of selected harmful elements originated from installation. The main factors that can affect the final results of drinking water analyses and should therefore be included in the drinking water sampling protocol were also indicated. Water chemical composition and selected physical parameters as well as house characteristics (kind of household) and water connection system features (material and age of the connections, pipes and tap) were taken into consideration. This is one of the first such complex research that includes the wide scale of different factors associated with tap water chemical composition. Multivariate analysis of variance (MANOVA) was implemented to find out if the chemical composition differs within the categories of the analysed parameters. If so, the parameters were deemed relevant for the sampling protocol. Otherwise, the influence of the parameters on the elemental content is insignificant.

\section{Study Area}

Research was conducted in the five cities located in southern Poland (Figure 1).

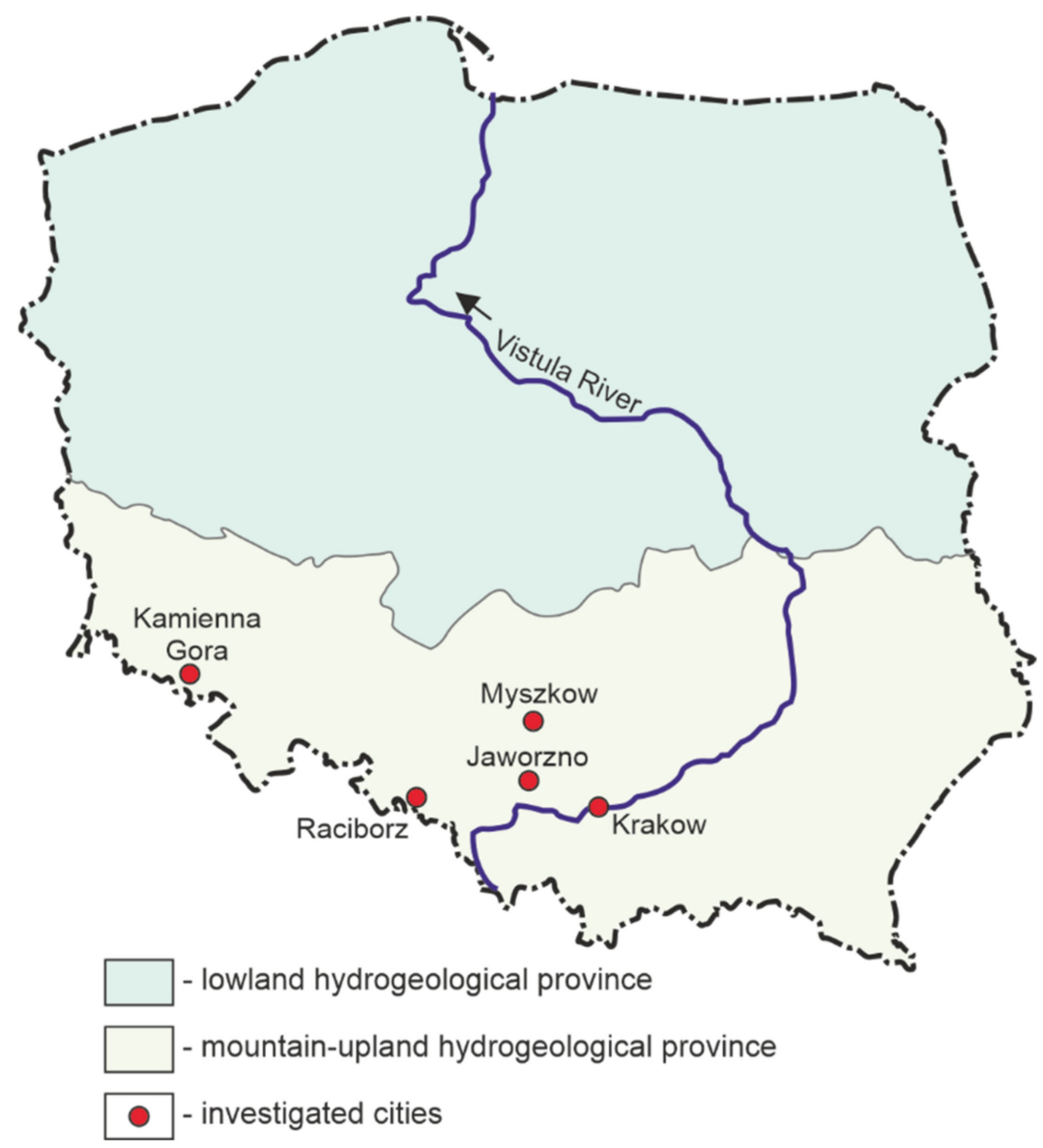

Figure 1. Location of the study area.

Poland has a warm temperate transitional climate. The climate zone is crossed by air masses from the Atlantic Ocean and Eurasian landmass [64]. The average annual precipitation is approximately $700 \mathrm{~mm}$ in central Poland, and toward the south, it increases to $780 \mathrm{~mm}$ in the uplands belt and $1100 \mathrm{~mm}$ in the mountains [64]. In case of evapotranspiration, this parameter can affect the chemical composition of drinking water, the main source of which is surface water such as in Krakow. The annual average value of evapotranspiration in Krakow based on the observation made by the meteorological station is $657.9 \mathrm{~mm}$ (http:/ / meteo.kdwd.webd.pl/wxetseason.php?r=wxetseason.php, accessed date: 8 November 2021). 
The examined area lies within the mountain-upland hydrogeological province where fresh groundwater is formed in the Sudetic Massif (MS), Carpathian Massif (MC), Świętokrzyski Massif (MSt) and Kujawski Massif (MKu). Within described massifs, the dominant bedrock is the fissured crystalline rocks (MS), Neogene-Paleogenic and cretaceous flysch rocks of fissure-pore nature (MK), fissure-karst Devonian carbonate rocks and Jurassic-Cretaceous carbonate rocks, as well as fissure-pore Jurassic-Cretaceous sandstone formations (MSt). The Kujawski massif is built mainly from Jurassic rocks of karst-fissure nature $[65,66]$. Detailed information on the geological setting within each city is presented in Table 1.

Table 1. Geological setting of groundwater used as a source of drinking water.

\begin{tabular}{cc}
\hline City & Geological Setting \\
\hline Myszkow & $\begin{array}{c}\text { Carbonate series of Middle Triassic (Muschelkalk), formed as } \\
\text { cracked karstic fissured dolomites and limestones }\end{array}$ \\
\hline Jaworzno & $\begin{array}{c}\text { Formations of carbonate series of Lower and Middle Triassic } \\
\text { and sandstone series of Upper Carboniferous }\end{array}$ \\
\hline Raciborz & $\begin{array}{c}\text { Pleistocene groundwater reservoir with sandy and } \\
\text { gravely formations }\end{array}$ \\
\hline Kamienna Gora & $\begin{array}{c}\text { Pleistocene groundwater reservoir with gravely formations, } \\
\text { covered with loams, silts, and contemporary river alluvia }\end{array}$ \\
\hline
\end{tabular}

\section{Materials and Methods}

Samples were taken from households in five Polish cities, Krakow, Raciborz, Jaworzno, Myszkow, and Kamienna Gora in accordance with the ISO 5667-3 [67]. The samples were collected at a random time of the working day directly from the tap without previous flushing (random daytime (RDT) samples) [23]. The collected information included 10 metals and metalloids: $\mathrm{Al}, \mathrm{As}, \mathrm{Cd}, \mathrm{Cr}, \mathrm{Cu}, \mathrm{Fe}, \mathrm{Mn}, \mathrm{Zn}, \mathrm{Ni}$, and $\mathrm{Pb}$ and auxiliary chemical indices such as major ions to control the correctness of the chemical analyses made. In total, 500 samples were collected (from 99 to 101 samples in each city). Blank samples (deionized water treated in the same way as normal samples) were also taken at 10 randomly selected locations in each city. In the field, $\mathrm{pH}$ and electrical conductivity (EC) (using automatic compensation to $25^{\circ} \mathrm{C}$ ) were measured using a Multi 350i meter, WTW, Weilheim, Germany, according to ISO 10523 [68] and EN 27888 [69] standards. Basic information about the water source, mean values of TDS (calculated as a sum of all analysed cations and anions), $\mathrm{pH}, \mathrm{EC}$, concentration of $\mathrm{Ca}, \mathrm{Mg}, \mathrm{SO}_{4}, \mathrm{HCO}_{3}$ ions and water treatment process in each city are summarised in Table 2. The dominating major ions in water analysed are $\mathrm{HCO}_{3}$ and $\mathrm{Ca}$. The hydrochemical type of water from Jaworzno, Kamienna Gora and Myszkow is $\mathrm{HCO}_{3}-\mathrm{SO}_{4}-\mathrm{Ca}-\mathrm{Mg}$, in Krakow it is $\mathrm{HCO}_{3}-\mathrm{SO}_{4}-\mathrm{Ca}$ water and in Raciborz $\mathrm{HCO}_{3}-\mathrm{Ca}-\mathrm{Mg}$.

The water samples were analysed in the laboratory of the Department of Hydrogeology and Engineering Geology, AGH University of Science and Technology, Krakow, Poland. The analyses of $\mathrm{Al}, \mathrm{As}, \mathrm{Cd}, \mathrm{Cr}, \mathrm{Cu}, \mathrm{Fe}, \mathrm{Mn}, \mathrm{Zn}, \mathrm{Ni}, \mathrm{Pb}$ were performed using inductively coupled plasma mass spectrometry (ICP-MS) with an ELAN 6100 spectrometer (Perkin Elmer, Waltham, MA, USA) in compliance with ISO 17294-2 [70]. Ca, Mg and S (recalculated on $\mathrm{SO}_{4}$ ) were determined using inductively coupled plasma optical emission spectrometry (ICP-OES) with an Optima 7300 DV spectrometer (Perkin Elmer, Waltham, MA, USA) according to ISO 11885 [71]. Titration methods were implemented for alkalinity $\left(\mathrm{HCO}_{3}{ }^{-}\right)$determination. The laboratory has implemented an internal QA/QC programme. As a part of quality control, it participates in proficiency tests and interlaboratory comparisons (PT/ILC), including in the field of heavy metal analysis in water intended for human consumption, achieving satisfactory results. Moreover, the duplicate samples and certified reference materials (TMDA 63.4) with a known matrix underwent the analysis during routine laboratory work. Basic method parameters were evaluated based on the results of multiple analyses of the certified reference material. The precision obtained 
during the chemical analyses was lower than $10 \%$, and the accuracy was in the range of $80 \%$ to $120 \%$. The relative pair difference calculated for duplicate samples did not exceed $13 \%$. The relative expanded uncertainty calculated for the analysed elements varied from $10 \%$ to $18 \%$.

Table 2. Basic water parameters.

\begin{tabular}{|c|c|c|c|c|c|c|c|c|c|c|}
\hline \multirow[t]{2}{*}{ City } & \multirow{2}{*}{$\begin{array}{l}\text { Water } \\
\text { Source }\end{array}$} & \multirow{2}{*}{$\begin{array}{l}\text { Number of } \\
\text { Samples }\end{array}$} & $\begin{array}{c}\text { TDS } \\
{[\mathrm{mg} / \mathrm{L}]}\end{array}$ & $\mathrm{pH}$ & $\begin{array}{c}\mathrm{EC} \\
{[\mu \mathrm{S} / \mathrm{cm}]}\end{array}$ & $\begin{array}{c}\mathrm{Ca}^{2+} \\
{[\mathrm{mg} / \mathrm{L}]}\end{array}$ & $\begin{array}{c}\mathrm{Mg}^{2+} \\
{[\mathrm{mg} / \mathrm{L}]}\end{array}$ & $\begin{array}{l}\mathrm{SO}_{4}{ }^{2-} \\
{[\mathrm{mg} / \mathrm{L}]}\end{array}$ & $\begin{array}{c}\mathrm{HCO}_{3}^{-} \\
{[\mathrm{mg} / \mathrm{L}]}\end{array}$ & \multirow{2}{*}{$\begin{array}{c}\text { Water Treatment } \\
\text { Process }\end{array}$} \\
\hline & & & \multicolumn{7}{|c|}{ Mean \pm SD } & \\
\hline Krakow & $\begin{array}{l}\text { Surface } \\
\text { water }\end{array}$ & 101 & $178 \pm 19$ & $7.1 \pm 0.4$ & $294 \pm 24$ & $41.7 \pm 5.0$ & $5.8 \pm 0.7$ & $45.8 \pm 7.7$ & $111 \pm 12$ & $\begin{array}{l}\text { ozonation } \\
\text { coagulation } \\
\text { sedimentation } \\
\text { filtration } \\
\text { disinfection }\end{array}$ \\
\hline Jaworzno & \multirow{4}{*}{ groundwater } & 100 & $450 \pm 37$ & $7.5 \pm 0.1$ & $760 \pm 17$ & $74.9 \pm 8.0$ & $40.4 \pm 3.8$ & $123 \pm 16$ & $266 \pm 18$ & disinfection \\
\hline $\begin{array}{c}\text { Kamienna } \\
\text { Gora }\end{array}$ & & 100 & $175 \pm 7$ & $6.8 \pm 0.1$ & $270 \pm 6$ & $32.6 \pm 2.1$ & $9.1 \pm 0.9$ & $62.2 \pm 7.2$ & $81.7 \pm 6.5$ & untreated \\
\hline Raciborz & & 100 & $315 \pm 46$ & $7.4 \pm 0.2$ & $560 \pm 64$ & $82.6 \pm 13.2$ & $16.1 \pm 3.1$ & $47.8 \pm 8.0$ & $274 \pm 43$ & $\begin{array}{c}\text { aeration } \\
\text { filtration } \\
\text { disinfection }\end{array}$ \\
\hline Myszkow & & 100 & $346 \pm 21$ & $7.3 \pm 0.1$ & $568 \pm 26$ & $71.0 \pm 9.0$ & $35.5 \pm 4.3$ & $58.1 \pm 14.4$ & $322 \pm 15$ & $\begin{array}{c}\text { aeration } \\
\text { disinfection } \\
\text { (if necessary) }\end{array}$ \\
\hline
\end{tabular}

SD: standard deviation.

In addition, anonymous voluntary survey data was collected for the research. The information was gathered from the adult household residents during a short-field voluntarily given interview in accordance with the current Polish law on data protection (The Personal Data Protection Act, no. 1000 of 2018). The experimental protocol, which included sampling procedures and the gathering of additional information from householders, was approved by the Polish National Committee of COST Action 637 "Meteau" (Metals and Related Substances in Drinking Water). All respondents were of legal age (over 18 years) and gave their informed consent to participate in the study. Among others, the questionnaire contained inquiries about the kind of household, water rating by end-user, age and material of pipe-work, connections and appliance and water stagnation time. These factors that could affect the results of the drinking water analysis were categorised according to the information collected during the field interview. The list of categories for each factor is available in Table 3.

Table 3. Categories established for survey descriptive variables collected during the field interview.

\begin{tabular}{cc}
\hline Factor & Categories \\
\hline City & Krakow \\
Jaworzno \\
Kamienna Gora \\
Raciborz \\
Myszkow \\
\hline Kind of household & public building \\
& block of flats \\
& house \\
\hline Age of connection & 10 years \\
& $10-30$ years \\
& 30 years \\
\hline Age of pipe-work & 10 years \\
& $10-30$ years \\
& 30 years \\
\hline
\end{tabular}


Table 3. Cont.

\begin{tabular}{cc}
\hline Factor & Categories \\
\hline Age of tap & 10 years \\
& $10-30$ years \\
Stagnation time & 30 years \\
& $1 \mathrm{~h}$ \\
\hline Material of connection & stainless steel \\
& iron \\
& plastic \\
& galvanised steel \\
& other \\
\hline Material of pipe-work & stainless steel \\
& copper \\
& iron \\
& plastic \\
& galvanised steel \\
& other \\
\hline Material of appliance & stainless steel \\
& other \\
\hline \multirow{2}{*}{ Water rating by end-user } & good \\
& unacceptable \\
\hline
\end{tabular}

\subsection{Data Analysis}

Data were interpreted using different statistical methods. Box-and-whiskers plots were used to show the variation in selected elements concentrations depending on the factor selected. Pearson correlation was applied to indicate dependencies between the analysed elements.

As a final part of the statistical analysis, multivariate analysis of variance (MANOVA) was applied [72]. The R package [73] was used to perform the MANOVA analysis. It was implemented to verify our hypothesis that the studied water sampling factors affect the concentrations of metals in water. The test was performed for each dependent variable (factor). To meet the assumptions of MANOVA, the univariate and multivariate outliers were identified and removed from each category. Only independent variables (metals and metalloids concentrations) characterised by the normal distribution for each category underwent MANOVA. The number of samples in each category range from 10 to 296, and the lowest was achieved for the different types of connection, pipe-works, and taps materials. Since the assumption of the covariance equality between categories was violated and the data were unbalanced (sizes of categories were not equal), the MANOVA test may have lost some sensitivity and thus Pillai's statistic was applied. The null hypothesis stated that there is no statistically significant difference in the metals content between the categories and the alternative hypothesis stated otherwise. The null hypothesis failed to be rejected with $p$-values above the established threshold equal to 0.05 . All values below 0.05 indicated that there is enough evidence to reject the null hypothesis and conclude that the metals content differs significantly between the categories. This further leads to regard these factors as potentially influencing the metals content during the water sampling and indicates that the variability related to this factor is remarkable and therefore this factor should be controlled during sampling.

\subsection{Risk Assessment}

Trace elements that occur in drinking water can pose a health risk to consumers primarily by ingestion $[5,7,11-13,33,34,42,74]$. For this reason, the human health risk (carcinogenic and non-carcinogenic) was assessed in relation to $\mathrm{Al}, \mathrm{As}, \mathrm{Cd}, \mathrm{Cr}, \mathrm{Cu}, \mathrm{Fe}, \mathrm{Mn}$, $\mathrm{Zn}, \mathrm{Ni}$ and $\mathrm{Pb}$. Chronic daily intake (CDI), hazard quotient (HQ), hazard index (HI) as a 
sum of the HQ arising from each element in the analysed samples, and cancer risk (CR) were calculated using the following formulae (Equations (1)-(4)) [11,42,67,68]:

$$
\begin{gathered}
\mathrm{CDI}=\frac{\mathrm{CW} \cdot \mathrm{IRW} \cdot \mathrm{EF} \cdot \mathrm{ED}}{\mathrm{BW} \cdot \mathrm{AT}} \\
\mathrm{HQ}=\frac{\mathrm{CDI}}{\mathrm{RfD}} \\
\mathrm{HI}=\sum \mathrm{HQ} \\
\mathrm{CR}=\mathrm{CDI} \cdot \mathrm{SF}
\end{gathered}
$$

where $\mathrm{CDI}$ is chronic daily intake $(\mathrm{mg} / \mathrm{kg} /$ day), $\mathrm{CW}$ is concentration of selected elements in water $(\mathrm{mg} / \mathrm{L}), \mathrm{IRW}$ is water ingestion rate (L), EF is exposure frequency (day/year), ED is exposure duration (years), BW is body weight $(\mathrm{kg})$, AT is average exposure duration time (days), RfD is reference dose of a specific element (mg/ $\mathrm{kg} /$ day), HQ is hazard quotient (-), $\mathrm{HI}$ is hazard index (-), CR is cancer risk (mg/ kg/day), and SF is slope factor (-). Risk was assessed in the division to two groups of people, children and adults. The values of the parameters used to estimate the exposure assessment of the analysed elements in the water

\begin{tabular}{|c|c|c|c|}
\hline \multirow{2}{*}{ Parameters } & \multirow{2}{*}{ Unit } & \multicolumn{2}{|c|}{ Value } \\
\hline & & Children & Adult \\
\hline IRW & $\mathrm{L}$ & 1 & 2 \\
\hline $\mathrm{EF}$ & day/year & 365 & 365 \\
\hline ED & Year & 6 & 30 \\
\hline BW & $\mathrm{Kg}$ & 15 & 70 \\
\hline AT (non-carcinogenic) & Days & 2190 & 25,550 \\
\hline AT (carcinogenic) & Days & \multicolumn{2}{|c|}{25,550} \\
\hline RfD (As) & \multirow{10}{*}{$\mathrm{mg} / \mathrm{kg} /$ day } & \multicolumn{2}{|c|}{0.0003} \\
\hline $\mathrm{RfD}(\mathrm{Al})$ & & \multicolumn{2}{|c|}{1} \\
\hline $\operatorname{RfD}(\mathrm{Cd})$ & & \multicolumn{2}{|c|}{0.001} \\
\hline $\mathrm{RfD}(\mathrm{Cr})$ & & \multicolumn{2}{|c|}{0.003} \\
\hline $\mathrm{RfD}(\mathrm{Cu})$ & & \multicolumn{2}{|c|}{0.04} \\
\hline provisional RfD (Fe) & & \multicolumn{2}{|c|}{0.7} \\
\hline RfD (Mn) & & \multicolumn{2}{|c|}{0.14} \\
\hline $\mathrm{RfD}(\mathrm{Ni})$ & & \multicolumn{2}{|c|}{0.02} \\
\hline $\mathrm{RfD}(\mathrm{Pb})$ & & \multicolumn{2}{|c|}{0.014} \\
\hline $\operatorname{RfD}(\mathrm{Zn})$ & & \multicolumn{2}{|c|}{0.3} \\
\hline SF (As) & & \multicolumn{2}{|c|}{1.5} \\
\hline $\mathrm{SF}(\mathrm{Al})$ & & \multicolumn{2}{|c|}{ not assessed } \\
\hline $\mathrm{SF}(\mathrm{Cd})$ & & \multicolumn{2}{|c|}{6.3} \\
\hline $\mathrm{SF}(\mathrm{Cr})$ & $\mu \mathrm{g} / \mathrm{g} /$ day & \multicolumn{2}{|c|}{0.5} \\
\hline $\mathrm{SF}(\mathrm{Cu})$ & & \multicolumn{2}{|c|}{ not assessed } \\
\hline $\mathrm{SF}(\mathrm{Fe})$ & & \multicolumn{2}{|c|}{ not assessed } \\
\hline $\mathrm{SF}(\mathrm{Mn})$ & & \multicolumn{2}{|c|}{ not assessed } \\
\hline
\end{tabular}
samples are summarized in Table 4.

Table 4. Parameters used to estimate exposure assessment of analysed elements in water samples $[11,34,42,74-78]$. 
Table 4. Cont.

\begin{tabular}{cccc}
\hline \multirow{2}{*}{ Parameters } & Unit & \multicolumn{2}{c}{ Value } \\
\cline { 4 - 4 } & & & \multicolumn{2}{c}{ Children } \\
\hline $\mathrm{SF}(\mathrm{Ni})$ & & \multicolumn{2}{c}{0.0085} \\
\hline $\mathrm{SF}(\mathrm{Pb})$ & & \multicolumn{2}{c}{ Adult } \\
\hline $\mathrm{SF}(\mathrm{Zn})$ & & \multicolumn{2}{c}{ not assessed } \\
& &
\end{tabular}

Non-carcinogenic risk expressed as $\mathrm{HI}$ (as a sum of $\mathrm{HQ}$ for each element) was classified as negligible $(\mathrm{HI}<0.1)$, low risk $(0.1 \leq \mathrm{HI}<1)$, medium $(1 \leq \mathrm{HI}<4)$ and high $(\mathrm{HI} \geq 4)[76,79]$. An acceptable value of the carcinogenic risk calculated as CR was adopted at the level of $1 \times 10^{-4}[80]$.

\section{Results}

The concentrations of the major ions differ significantly between cities and are mainly associated with the natural composition of the water distributed in the analysed regions. The differences between cities mostly come from the type of distributed water (i.a., surface or groundwater) and their chemical composition before any treatment (the so-called raw water), and the type of treatment processes applied in water treatment plants. Therefore, only total concentrations of selected heavy metals and metalloids which present in drinking water is related to the water distribution system properties rather than to natural factors, were analysed [23,81].

The results obtained for the blank samples were below the method detection limits. Basic statistics for the concentrations of elements analysed in the collected water samples, together with the maximum permissible concentrations in drinking water set in European (EU 2020 [19]) and worldwide (WHO 2017 [82]) standards are presented in Table 5.

Table 5. Statistics for trace elements concentrations in the collected water samples.

\begin{tabular}{ccccccccc}
\hline Variable & $\begin{array}{c}\text { Parametric } \\
\text { Value [7] } \\
{[\mu \mathrm{g} / \mathrm{L}]}\end{array}$ & $\begin{array}{c}\text { Guideline } \\
\text { Value }[47] \\
{[\mu \mathrm{g} / \mathrm{L}]}\end{array}$ & $\begin{array}{c}\text { Mean } \\
{[\mu \mathrm{g} / \mathrm{L}]}\end{array}$ & $\begin{array}{c}\text { 5\% Trimmed } \\
\text { Mean } \\
{[\mu \mathrm{g} / \mathrm{L}]}\end{array}$ & $\begin{array}{c}\text { Median } \\
{[\mu \mathrm{g} / \mathrm{L}]}\end{array}$ & $\begin{array}{c}\text { Standard } \\
\text { Deviation } \\
{[\mu \mathrm{g} / \mathrm{L}]}\end{array}$ & $\begin{array}{c}\text { Minimum } \\
{[\mu \mathrm{g} / \mathrm{L}]}\end{array}$ & $\begin{array}{c}\text { Maximum } \\
{[\mu \mathrm{g} / \mathrm{L}]}\end{array}$ \\
\hline $\mathrm{As}$ & 10 & 10 & 0.72 & 0.70 & 0.65 & 0.38 & 0.18 & 3.39 \\
\hline $\mathrm{Cr}$ & 50 & 50 & 4.85 & 4.64 & 4.45 & 2.97 & 0.03 & 54.26 \\
\hline $\mathrm{Zn}$ & -1 & - & 650 & 525 & 365 & 930 & 11,377 \\
\hline $\mathrm{Al}$ & 200 & - & 11.64 & 10.52 & 3.19 & 17.42 & 0.15 & 149.4 \\
\hline $\mathrm{Cd}$ & 5 & 3 & 0.53 & 0.42 & 0.18 & 0.74 & 0.002 & 4.73 \\
\hline $\mathrm{Mn}$ & 50 & - & 16.26 & 12.00 & 6.08 & 28.34 & 0.04 & 336.9 \\
\hline $\mathrm{Cu}$ & 2000 & 2000 & 38.21 & 18.92 & 11.01 & 118.1 & 0.09 \\
\hline $\mathrm{Ni}$ & 20 & 70 & 3.73 & 2.28 & 1.93 & 19.91 & 0.02 & 433.8 \\
\hline $\mathrm{Pb}$ & 10 & 10 & 5.43 & 4.21 & 1.77 & 8.68 & 0.10 \\
\hline $\mathrm{Fe}$ & 200 & - & 202 & 159 & 104 & 282 & 75.69 \\
\hline
\end{tabular}

The variability of the concentration of trace elements between the categories of the descriptive variables is shown in the form of box plots (Supplementary Materials Figure S1). In Figure 2, selected results for Fe and Mn are presented for which the differences were most pronounced. The results were also compared with the requirements of European [19] and international [82] regulations.

Human health risk was calculated for both children and adults, taking into account oral exposure. $\mathrm{CDI}, \mathrm{HQ}, \mathrm{HI}$ and $\mathrm{CR}$ were computed individually for each sampling point. Table 6 presents the range and mean values of the calculated parameters. 

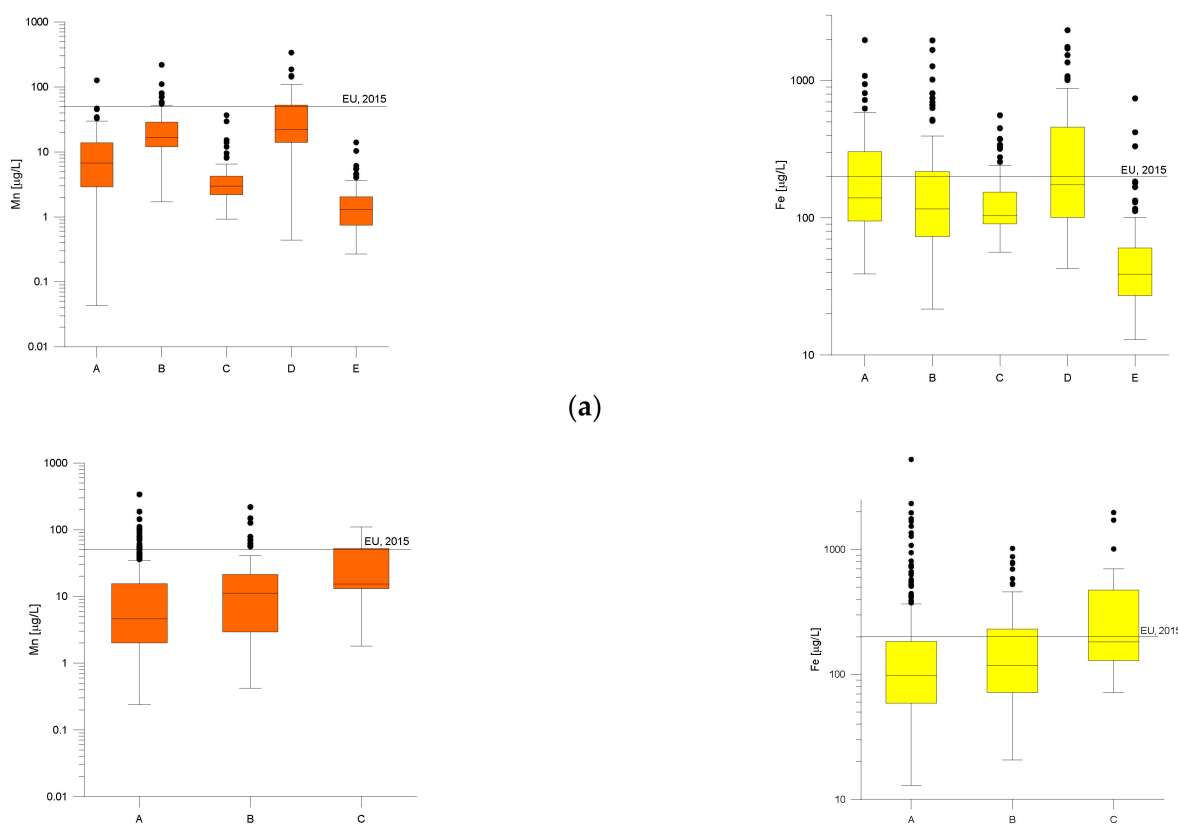

(a)

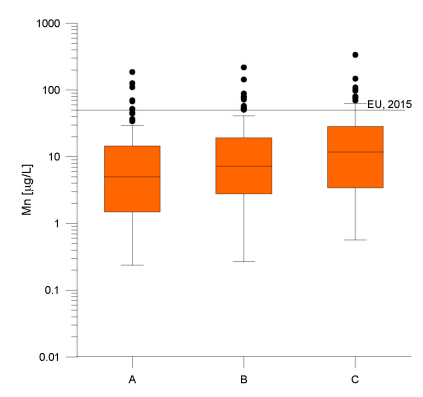

(b)

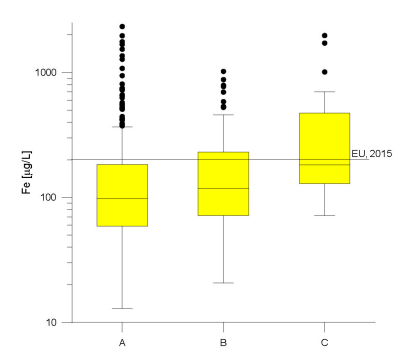

(c)
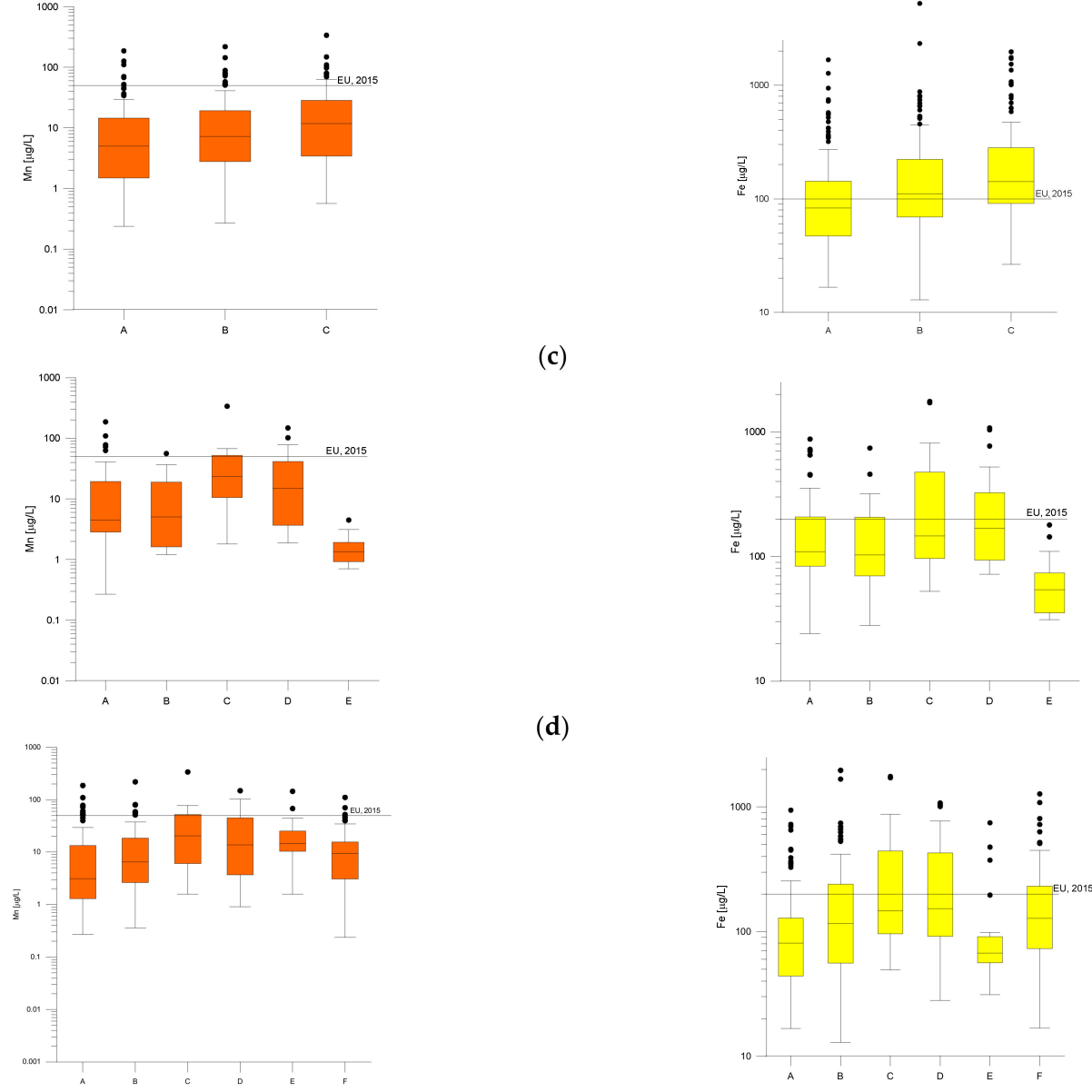

(d)

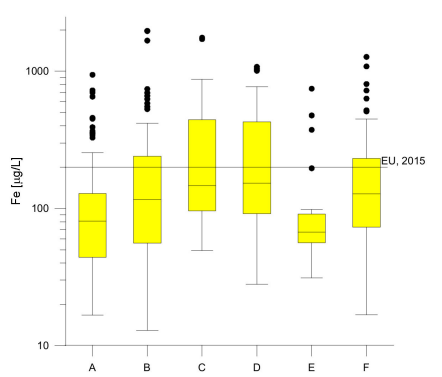

(e)

Figure 2. Fe and Mn concentrations in the water analysed by selected categories of factors. (a) City: A, Krakow; B, Jaworzno; C, Kamienna Gora; D, Raciborz; E, Myszkow. (b) Age of tap: A, <10 years; B, 10-30 years; C, >30 years. (c) Age of pipe-work: A, <10 years; B, 10-30 years; C, >30 years. (d) Material of connection: A, PCV; B, steel; C, galvanised steel; D, stainless steel; E, other. (e) Material of pipe-work: A, PCV; B, steel; C, galvanised steel; D, stainless steel; E, copper; F, other. 
Table 6. Basic statistics for calculated risk.

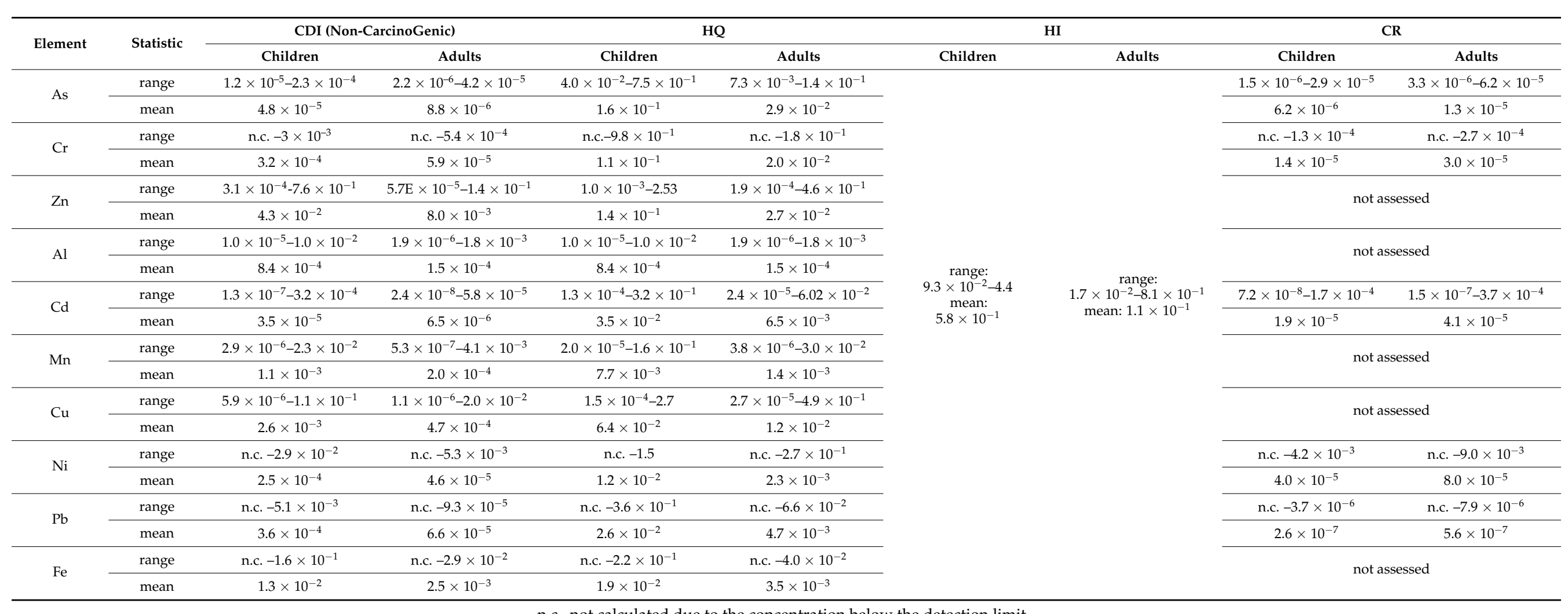

n.c., not calculated due to the concentration below the detection limit. 


\section{Discussion}

The parametric values (PVs) were exceeded for cadmium, manganese, nickel, lead and iron. PVs for lead must be decreased to $5 \mu \mathrm{g} / \mathrm{L}$ by 12 January 2036 and for chromium to $25 \mu \mathrm{g} / \mathrm{L}$ [19]. Taking into account these PVs, some exceedances occur also in terms of the observed $\mathrm{Cr}$ concentrations. Selected results close to PVs were detected for copper, chromium and aluminium. When related expanded uncertainty is also included in the decision process, more results should be classified as above PVs. However, for the purpose of the presented evaluation, the simple deterministic method was used. It can be observed that the oldest connections during the long-time of work have been undergoing material corrosion; therefore, a significant amount of lead, zinc and iron can be released into the tap water. The new ones which are produced of copper can enrich tap water in $\mathrm{Cu}$ ions during the first years of work. While the copper material ages, it is covered with a patina that prevents further releasing $\mathrm{Cu}$ ions into water. From the collected data, heavy metals and metalloids such as $\mathrm{As}, \mathrm{Cd}, \mathrm{Cr}, \mathrm{Cu}, \mathrm{Fe}, \mathrm{Mn}, \mathrm{Ni}$ and $\mathrm{Pb}$ showed the relationship between their concentrations in tap water and facilities used to provide water to households (Figures 2 and S1). As many authors suggest (e.g., [83-85]) the usage of Albased coagulants may result in an increase of $\mathrm{Al}$ concentration in tap water. Some studies proved that up to $11 \%$ of the aluminium input could remain in the treated water [83]. This phenomenon is typical in situations where surface water is used as a source of raw water. As the results indicated, the age of connection, pipe-work and tap mostly influence $\mathrm{As}, \mathrm{Cr}$, $\mathrm{Cd}, \mathrm{Cu}, \mathrm{Ni}$ and $\mathrm{Pb}$ concentrations regardless of the city. The material of installation affects the final amount of $\mathrm{Al}, \mathrm{As}, \mathrm{Cd}$ and $\mathrm{Cr}$. Figure 3 graphically presents the correlations for trace elements that are preferentially released to tap water. It can be seen that Fe occurs more often with $\mathrm{Mn}$ (natural co-existence) and $\mathrm{Cd}, \mathrm{Pb}$ and $\mathrm{Zn}$ usually appear together. It is well understood since galvanised steel is produced from $\mathrm{Zn}-\mathrm{Pb}$ ores containing $\mathrm{Cd}$ as an accessory metal. The corrosion of $\mathrm{Zn}$ alloys leads to the release of those metals in various proportions. It is typical for pipes older than 25-30 years.

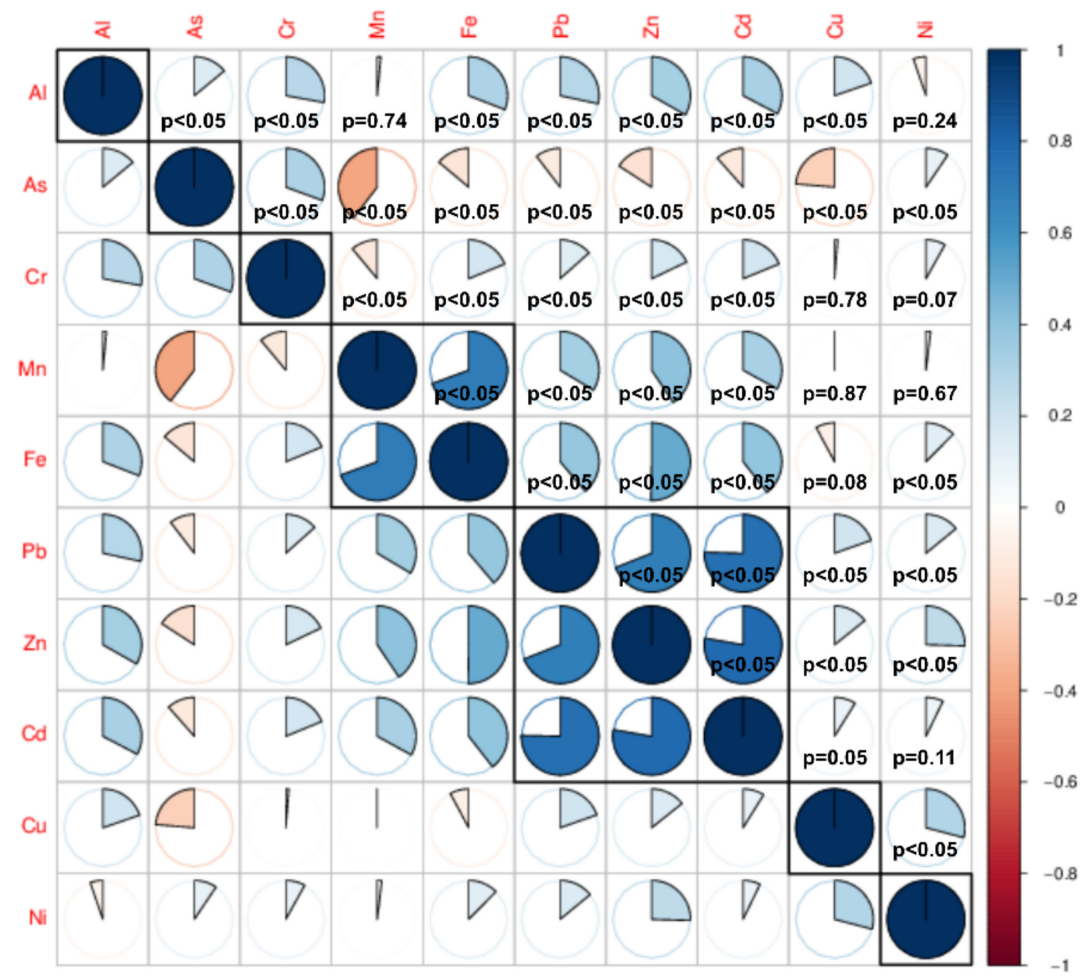

Figure 3. Correlations between heavy metals in tap water. Correlation is statistically significant when the $p$-value is equal to or lower than 0.05 . 
However, the concentrations of $\mathrm{Fe}, \mathrm{Mn}$ and $\mathrm{Zn}, \mathrm{Pb}, \mathrm{Cd}$ can have a major source in the material and the length of the distribution pipes [86]. The results of the presented research show that the concentrations of Fe and Mn increase with the growth of the age of the tap and pipe-works (Figure 2). The differences also occur depending on the material of connection and pipe-work and are particularly visible in terms of As, $\mathrm{Al}, \mathrm{Cd}, \mathrm{Cr}, \mathrm{Fe}$, $\mathrm{Mn}, \mathrm{Pb}$ and $\mathrm{Zn}$ concentrations (Figures 2 and S1, Table 7) and are statistically significant (Figure 3). Gao et al. [87] reported that among the inorganic compounds found in the pipe scales and loose deposits, Fe had the highest concentration which was followed by $\mathrm{Al}, \mathrm{Mn}$, $\mathrm{Zn}, \mathrm{Cu}, \mathrm{Ni}, \mathrm{Cr}, \mathrm{Pb}, \mathrm{As}$ and $\mathrm{Cd}$. Iron can also be released in the ferrous form from corroded, old galvanised pipes [88].

Table 7. Results of MANOVA for selected trace elements concentrations in tap water.

\begin{tabular}{ccc}
\hline Factor & Variables & MANOVA $p$-Value \\
\hline City & $\mathrm{Zn}, \mathrm{Mn}$ & $p 0.05$ \\
\hline Age of connection & $\mathrm{As}, \mathrm{Cr}, \mathrm{Cu}, \mathrm{Ni}$ & $p 0.05$ \\
\hline Age of pipe-work & $\mathrm{Cr}, \mathrm{Cu}, \mathrm{Ni}$ & $p 0.05$ \\
\hline Age of tap & $\mathrm{Cr}, \mathrm{Zn}, \mathrm{Fe}$ & $p 0.05$ \\
\hline Material of connection & $\mathrm{As}, \mathrm{Zn}, \mathrm{Cu}, \mathrm{Ni}, \mathrm{Pb}, \mathrm{Fe}$ & $p 0.05$ \\
\hline Material of pipe-work & $\mathrm{Zn}, \mathrm{Ni}, \mathrm{Fe}$ & $p 0.05$ \\
\hline Material of appliance & $\mathrm{Zn}, \mathrm{Cu}, \mathrm{Ni}, \mathrm{Fe}$ & $p 0.05$ \\
\hline Water rating by end-user & $\mathrm{Cr}, \mathrm{Zn}, \mathrm{Ni}, \mathrm{Fe}$ & $p 0.05$ \\
\hline
\end{tabular}

The lowest concentrations of $\mathrm{Zn}, \mathrm{Pb}$ and $\mathrm{Cd}$ were found in the case of taps, pipe-works and connections in the age below 10 years, whereas the $\mathrm{Cu}$ concentration in this group reached the highest values. Both $\mathrm{Zn}$ and $\mathrm{Pb}$ can be affected by brass corrosion, although $\mathrm{Zn}$ can be preferentially released (Figure 3). This is reflected in the correlation found during the investigation carried out (Figure 3). This type of corrosion, called "dezincification" $[14,89,90]$ is generally less desirable than uniform corrosion because it persists over time which can lead to device failure [90]. Dezincification is also considered a major promoter of lead release [90,91]. Replacing or connecting of aged lead pipes with stainless steel ones can affect the $\mathrm{Pb}$ release to drinking water due to galvanic corrosion. The concentration of $\mathrm{Pb}$ decreases with $\mathrm{pH}$ and the higher chloride to sulphate mass ratio [92-94]. The network water supply system made of brass devices or lead solders may constitute a major source of $\mathrm{Pb}$ in tap water, not only in old but also in new buildings $[24,25,89,95]$.

The source of increased concentrations of zinc and copper can be correlated, among others, with a time of water stagnation in pipes [96,97]; however, in the presented research, this correlation was not indicated (Figure 3). Besides the pipe material and water stagnation time, the flow rate established before sampling affects the concentration of heavy metals in tap water [94]. The highest concentration of $\mathrm{Cu}$ in the new installation may result from the material of pipe-work and connection. Popular copper pipes in the first years of use can cause the entrance of $\mathrm{Cu}$ to the water (Figure 2). Furthermore, in Poland, the pipes used for the construction of the connection and internal pipe-work were covered with zinc from the Olkusz $\mathrm{Pb}-\mathrm{Zn}$ ores in which accompanying metals such as cadmium occur. The zinc refining process in the past did not allow for full separation; therefore, all these metals are present in the galvanised cladding. With the progress of zinc corrosion and increasing porosity of the $\mathrm{Zn}$ covering, some amounts of $\mathrm{Pb}$ and $\mathrm{Cd}$ may be released to the water.

The most significant differences in trace elements concentrations were observed between the five cities as shown in Figure 2 and Supplementary Materials Figure S1. Water rating by end-user is the most difficult factor to assess. It can be considered as Supplementary information. The results are difficult to interpret because of the subjective nature of this information. 
The grouping seems much less pronounced for the age of tap, connection or pipework, Material of connection or pipe-work factors. Material of appliance and water rating by the end-user factors demonstrate the remarkable overlap between categories.

Table 7 briefly summarises the variables considered for running the MANOVA test for each factor. Note that MANOVA was not performed for kind of household and stagnation time dependent variables due to the lack of normally distributed independent variables. The $p$-values pointed out if the differences of the trace elements concentrations between factor categories were statistically significant at the assumed level $(\alpha=0.05)$. Assuming $\alpha=0.05$ is associated with a $5 \%$ risk of concluding that a difference exists when there is actually no difference. Thus, the test is statistically significant if $p<0.05$. This result was obtained for all factors and the conclusions are that the differences of metals and metalloids concentrations differ statistically significantly between the studied factors categories. In other words, there is enough evidence to reject the null hypothesis and conclude that the metals content differs significantly between the categories. Thus, all factors should be controlled during water sampling since they all introduce significant variability in the metals content.

The most probable source of $\mathrm{Cr}$ and $\mathrm{Ni}$ are the alloys of taps, while $\mathrm{Cu}$ and $\mathrm{Zn}$ could be released from pipes and taps' corpuses made of bronze or brass [98]. High concentrations of $\mathrm{Ni}$ in tap water were also determined, i.e., by Andersen et al. [99], especially in samples collected directly from the taps without prior installation flush. They connected the occurrence of $\mathrm{Ni}$ in tap water with the materials of valves and chromium-nickel plated taps. The highest concentrations of Fe were found in installations made of stainless-steel and in samples collected after more than $1 \mathrm{~h}$ of water stagnation, which is most likely related to the progressive process of corrosion [100,101]. Meanwhile, $\mathrm{Cu}$ contents were higher in water samples collected from new installations. The release of $\mathrm{Cu}$ from the material of connection is controlled by many factors, such as the water temperature or $\mathrm{pH}[100,102]$. Zn can release from the galvanised pipes and other brass parts of water installation systems [103]. Clark et al. [104] found a strong correlation between $\mathrm{Pb}$ and $\mathrm{Zn}$ in samples collected from water systems containing galvanised steel pipes. Differences in Zn concentration in the City category can also be influenced by the groundwater intake located in the city of Jaworzno, which lies within the mining area of $\mathrm{Zn}-\mathrm{Pb}$ ores. The zinc concentration in raw groundwater in Jaworzno was the highest compared to four other cities, and is on average $0.3 \mathrm{mg} / \mathrm{L}$, while in other cities, it is absent (not measured/below the limit of detection of the analytical method) or it was quantified at the level of a dozen $\mu \mathrm{g} / \mathrm{L}$ [65].

Results of hazard analysis are presented in Figure 4.

For adults, HI was assessed as negligible in $59.1 \%$ of the sampling points and low in $40.9 \%$. Medium and high risk was not observed in the area analysed. Taking into consideration the non-carcinogenic risk for children, high risk was observed in one sample $(0.2 \%)$, medium in 45 samples $(9.0 \%)$, negligible in two samples $(0.4 \%)$ and low for the rest of the analysed samples (Figure 4). The high and medium risk (HI above 4 and between 1 and 4, respectively) evaluated for children arose mostly from medium HQ values for copper, zinc, lead and nickel. Elevated concentrations of these elements in water can be related to the age and material of the internal water installation (Table 7). The order of non-carcinogenic risk caused by the elements considered was $\mathrm{As} \cong \mathrm{Zn}>\mathrm{Cr} \cong \mathrm{Pb}>\mathrm{Cu}>\mathrm{Cd}$ $>\mathrm{Fe}>\mathrm{Ni}>\mathrm{Mn}>\mathrm{Al}$. In addition, Tian et al. [43] indicated the impact of water stagnation time in galvanised steel pipes on human health risk. Cancer risk (R) was evaluated only for $\mathrm{As}, \mathrm{Cd}, \mathrm{Cr}, \mathrm{Ni}$ and $\mathrm{Pb}$ because of the lack of carcinogenic character and, therefore, slope factor value for the rest of the elements considered. An unacceptable cancer risk for children was observed in one sample $(0.2 \%)$ for chromium, 18 samples $(3.6 \%)$ for nickel and 11 samples (2.2\%) for cadmium. Meanwhile, in the case of calculations made for adults, the exceedance of the acceptable limit of $1 \mathrm{E}-04$ was indicated in two samples $(0.4 \%)$ for chromium, 64 samples $(12.3 \%)$ for nickel and 57 samples $(11.4 \%)$ for cadmium (Figure 4). As MANOVA results indicated, both $\mathrm{Cr}$ and $\mathrm{Ni}$ concentrations depend on 
the age of pipe-work and age of connection. Additionally, the material of connection, pipe-work and appliance influence nickel concentration in tap water. The values of HQ, HI and CR determined individually for each city using mean concentrations of each element indicated that the carcinogenic risk for adults arises from nickel in the water of Kamienna Gora (Table 8). Low non-carcinogenic risk expressed as $\mathrm{HI}$ occurs in each city in a case of children oral exposure and in Jaworzno, Kamienna Gora and Raciborz in a case for adults.

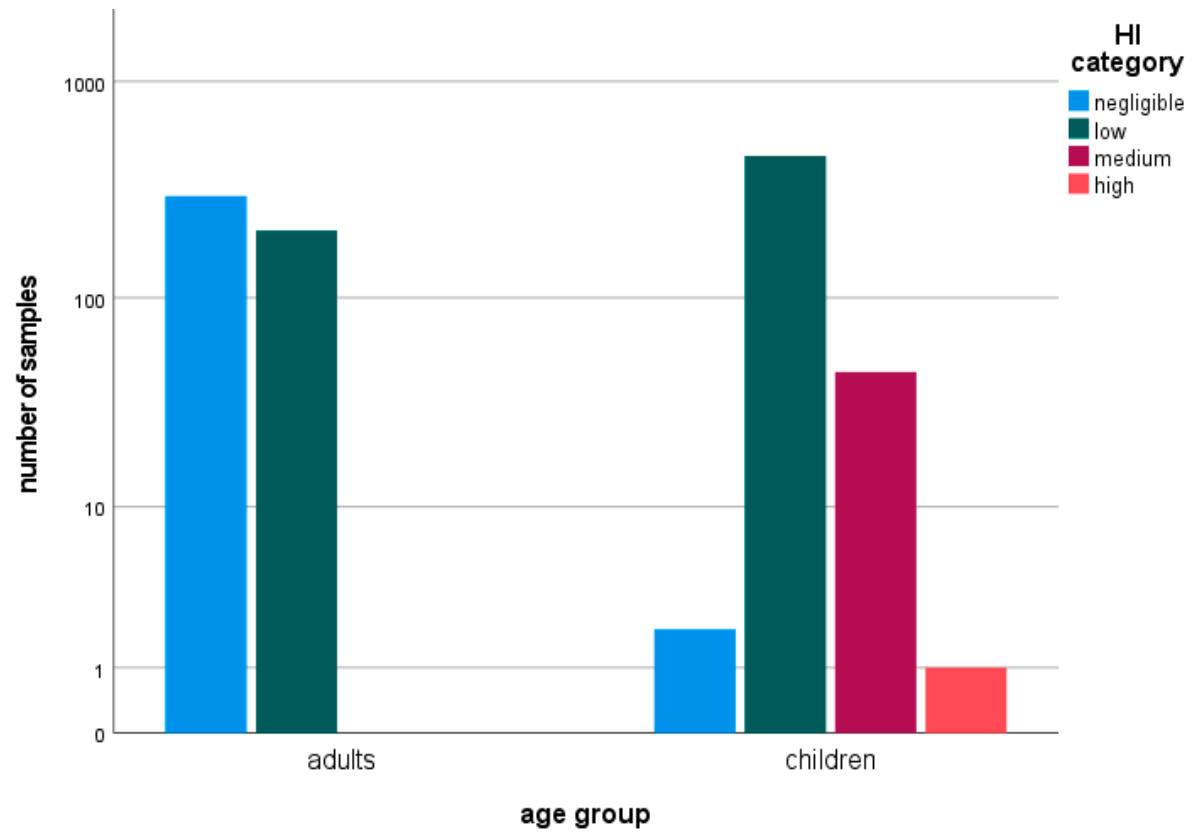

(a)

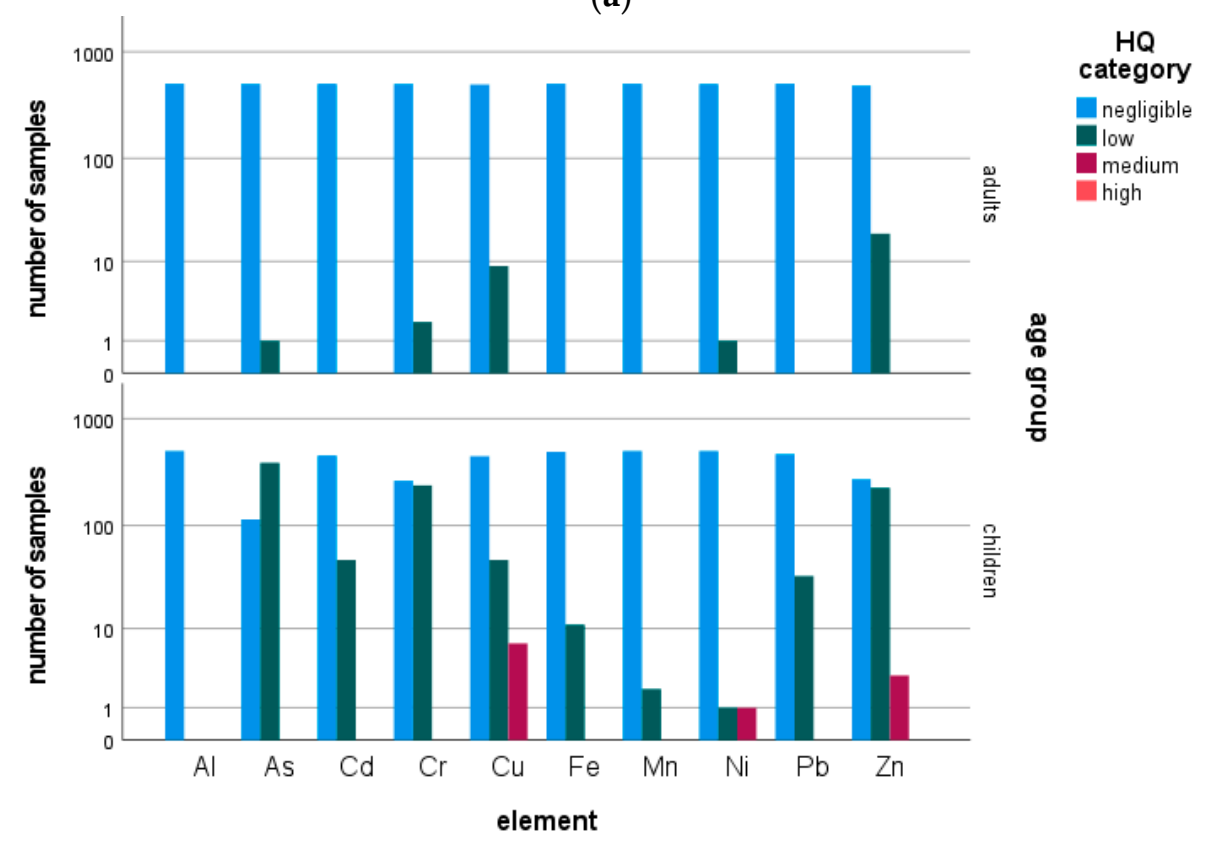

(b)

Figure 4. Cont. 


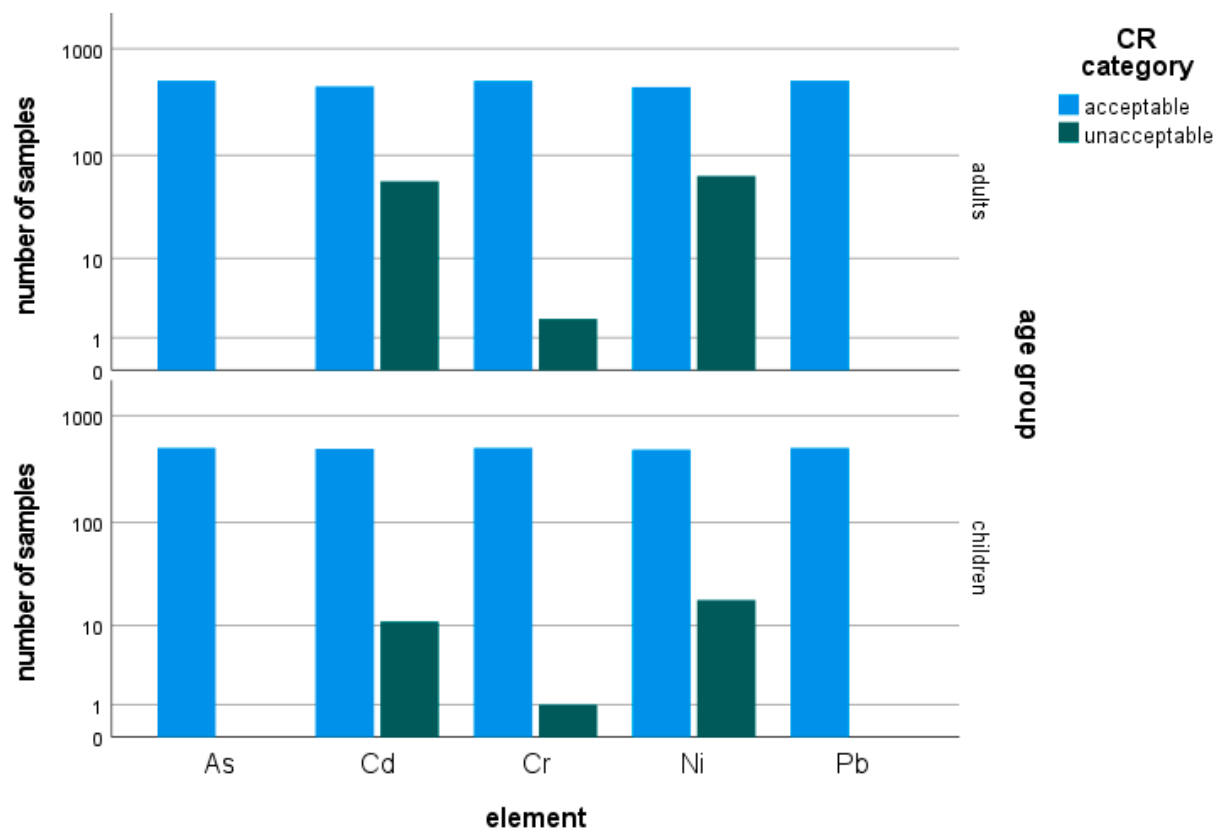

(c)

Figure 4. Summarised results for (a) HQ, (b) HI, and (c) CR.

Table 8. HQ, HI and CR values in each city.

\begin{tabular}{|c|c|c|c|c|c|c|c|}
\hline \multirow{2}{*}{ City } & \multirow{2}{*}{ Element } & \multicolumn{2}{|c|}{ HQ } & \multicolumn{2}{|c|}{ HI } & \multicolumn{2}{|c|}{ CR } \\
\hline & & Children & Adults & Children & Adults & Children & Adults \\
\hline \multirow{10}{*}{ Jaworzno } & As & $1.6 \times 10^{-1}$ & $3.0 \times 10^{-2}$ & \multirow{10}{*}{$7.8 \times 10^{-1}$} & \multirow{10}{*}{$1.4 \times 10^{-1}$} & $6.2 \times 10^{-6}$ & $1.3 \times 10^{-5}$ \\
\hline & $\mathrm{Cr}$ & $1.6 \times 10^{-1}$ & $2.9 \times 10^{-2}$ & & & $2.0 \times 10^{-5}$ & $4.3 \times 10^{-5}$ \\
\hline & $\mathrm{Zn}$ & $2.4 \times 10$ & $4.4 \times 10^{-2}$ & & & n.a. & n.a. \\
\hline & $\mathrm{Al}$ & $1.7 \times 10^{-3}$ & $3.2 \times 10^{-4}$ & & & n.a. & n.a. \\
\hline & $\mathrm{Cd}$ & $8.2 \times 10^{-2}$ & $1.5 \times 10^{-2}$ & & & $4.4 \times 10^{-5}$ & $9.4 \times 10^{-5}$ \\
\hline & Mn & $5.0 \times 10^{-3}$ & $9.2 \times 10^{-4}$ & & & n.a. & n.a. \\
\hline & $\mathrm{Cu}$ & $3.7 \times 10^{-2}$ & $6.8 \times 10^{-3}$ & & & n.a. & n.a. \\
\hline & $\mathrm{Ni}$ & $9.1 \times 10^{-2}$ & $1.7 \times 10^{-3}$ & & & $2.6 \times 10^{-5}$ & $5.7 \times 10^{-5}$ \\
\hline & $\mathrm{Pb}$ & $6.9 \times 10^{-2}$ & $1.3 \times 10^{-2}$ & & & $7.0 \times 10^{-7}$ & $1.5 \times 10^{-6}$ \\
\hline & $\mathrm{Fe}$ & $2.2 \times 10^{-2}$ & $4.1 \times 10^{-3}$ & & & n.a. & n.a. \\
\hline \multirow{10}{*}{$\begin{array}{c}\text { Kamienna } \\
\text { Gora }\end{array}$} & As & $6.2 \times 10^{-2}$ & $1.1 \times 10^{-2}$ & \multirow{10}{*}{$6.2 \times 10^{-1}$} & \multirow{10}{*}{$1.1 \times 10^{-1}$} & $2.4 \times 10^{-6}$ & $5.2 \times 10^{-6}$ \\
\hline & $\mathrm{Cr}$ & $9.4 \times 10^{-2}$ & $1.7 \times 10^{-2}$ & & & $1.2 \times 10^{-5}$ & $2.6 \times 10^{-5}$ \\
\hline & $\mathrm{Zn}$ & $1.8 \times 10^{-1}$ & $3.4 \times 10^{-2}$ & & & n.a. & n.a. \\
\hline & $\mathrm{Al}$ & $2.0 \times 10^{-4}$ & $3.6 \times 10^{-5}$ & & & n.a. & n.a. \\
\hline & $\mathrm{Cd}$ & $2.5 \times 10^{-2}$ & $4.5 \times 10^{-3}$ & & & $1.3 \times 10^{-5}$ & $2.9 \times 10^{-5}$ \\
\hline & $\mathrm{Mn}$ & $1.2 \times 10^{-2}$ & $2.2 \times 10^{-3}$ & & & n.a. & n.a. \\
\hline & $\mathrm{Cu}$ & $1.8 \times 10^{-1}$ & $3.2 \times 10^{-2}$ & & & n.a. & n.a. \\
\hline & $\mathrm{Ni}$ & $2.3 \times 10^{-2}$ & $4.2 \times 10^{-3}$ & & & $6.6 \times 10^{-5}$ & $1.4 \times 10^{-4}$ \\
\hline & $\mathrm{Pb}$ & $2.7 \times 10^{-2}$ & $4.9 \times 10^{-3}$ & & & $2.7 \times 10^{-7}$ & $5.8 \times 10^{-7}$ \\
\hline & $\mathrm{Fe}$ & $2.2 \times 10^{-2}$ & $4.0 \times 10^{-3}$ & & & n.a. & n.a. \\
\hline
\end{tabular}


Table 8. Cont.

\begin{tabular}{|c|c|c|c|c|c|c|c|}
\hline \multirow{2}{*}{ City } & \multirow{2}{*}{ Element } & \multicolumn{2}{|c|}{ HQ } & \multicolumn{2}{|c|}{ HI } & \multicolumn{2}{|c|}{ CR } \\
\hline & & Children & Adults & Children & Adults & Children & Adults \\
\hline \multirow{10}{*}{ Krakow } & As & $1.7 \times 10^{-1}$ & $3.1 \times 10^{-2}$ & \multirow{10}{*}{$5.1 \times 10^{-1}$} & \multirow{10}{*}{$9.4 \times 10^{-2}$} & $6.6 \times 10^{-6}$ & $1.4 \times 10^{-5}$ \\
\hline & $\mathrm{Cr}$ & $1.1 \times 10^{-1}$ & $2.0 \times 10^{-2}$ & & & $1.4 \times 10^{-5}$ & $3.0 \times 10^{-5}$ \\
\hline & $\mathrm{Zn}$ & $1.1 \times 10^{-1}$ & $2.1 \times 10^{-2}$ & & & n.a. & n.a. \\
\hline & $\mathrm{Al}$ & $2.0 \times 10^{-3}$ & $3.6 \times 10^{-4}$ & & & n.a. & n.a. \\
\hline & $\mathrm{Cd}$ & $1.9 \times 10^{-2}$ & $3.6 \times 10^{-3}$ & & & $1.1 \times 10^{-5}$ & $2.3 \times 10^{-5}$ \\
\hline & Mn & $2.0 \times 10^{-3}$ & $3.6 \times 10^{-4}$ & & & n.a. & n.a. \\
\hline & $\mathrm{Cu}$ & $6.7 \times 10^{-2}$ & $1.2 \times 10^{-2}$ & & & n.a. & n.a. \\
\hline & $\mathrm{Ni}$ & $7.5 \times 10^{-3}$ & $1.4 \times 10^{-3}$ & & & $2.2 \times 10^{-5}$ & $1.4 \times 10^{-3}$ \\
\hline & $\mathrm{Pb}$ & $8.8 \times 10^{-3}$ & $1.6 \times 10^{-3}$ & & & $9.0 \times 10^{-8}$ & $1.9 \times 10^{-7}$ \\
\hline & $\mathrm{Fe}$ & $1.3 \times 10^{-2}$ & $2.5 \times 10^{-3}$ & & & n.a. & n.a. \\
\hline \multirow{10}{*}{ Myszkow } & As & $1.7 \times 10^{-1}$ & $3.2 \times 10^{-2}$ & \multirow{10}{*}{$5.5 \times 10^{-1}$} & \multirow{10}{*}{$1.0 \times 10^{-1}$} & $6.7 \times 10^{-6}$ & $1.4 \times 10^{-5}$ \\
\hline & $\mathrm{Cr}$ & $9.6 \times 10^{-2}$ & $1.8 \times 10^{-2}$ & & & $1.2 \times 10^{-5}$ & $2.7 \times 10^{-5}$ \\
\hline & $\mathrm{Zn}$ & $1.4 \times 10^{-1}$ & $2.6 \times 10^{-2}$ & & & n.a. & n.a. \\
\hline & $\mathrm{Al}$ & $2.4 \times 10^{-4}$ & $4.4 \times 10^{-5}$ & & & n.a. & n.a. \\
\hline & $\mathrm{Cd}$ & $4.1 \times 10^{-2}$ & $7.6 \times 10^{-3}$ & & & $2.2 \times 10^{-5}$ & $4.8 \times 10^{-5}$ \\
\hline & Mn & $1.9 \times 10^{-2}$ & $3.4 \times 10^{-3}$ & & & n.a. & n.a. \\
\hline & $\mathrm{Cu}$ & $1.2 \times 10^{-2}$ & $2.2 \times 10^{-3}$ & & & n.a. & n.a. \\
\hline & $\mathrm{Ni}$ & $7.4 \times 10^{-3}$ & $1.4 \times 10^{-3}$ & & & $2.2 \times 10^{-5}$ & $4.6 \times 10^{-5}$ \\
\hline & $\mathrm{Pb}$ & $2.1 \times 10^{-2}$ & $3.8 \times 10^{-3}$ & & & $2.1 \times 10^{-7}$ & $4.5 \times 10^{-7}$ \\
\hline & $\mathrm{Fe}$ & $3.3 \times 10^{-2}$ & $6.0 \times 10^{-3}$ & & & n.a. & n.a. \\
\hline \multirow{10}{*}{ Raciborz } & As & $2.3 \times 10^{-1}$ & $4.3 \times 10^{-2}$ & \multirow{10}{*}{$4.3 \times 10^{-1}$} & \multirow{10}{*}{$7.9 \times 10^{-2}$} & $9.0 \times 10^{-6}$ & $1.9 \times 10^{-5}$ \\
\hline & $\mathrm{Cr}$ & $8.9 \times 10^{-2}$ & $1.6 \times 10^{-2}$ & & & $1.1 \times 10^{-5}$ & $2.5 \times 10^{-5}$ \\
\hline & $\mathrm{Zn}$ & $4.6 \times 10^{-2}$ & $8.4 \times 10^{-3}$ & & & n.a. & n.a. \\
\hline & $\mathrm{Al}$ & $8.0 \times 10^{-5}$ & $1.5 \times 10^{-5}$ & & & n.a. & n.a. \\
\hline & $\mathrm{Cd}$ & $9.3 \times 10^{-3}$ & $1.7 \times 10^{-3}$ & & & $5.0 \times 10^{-6}$ & $1.1 \times 10^{-5}$ \\
\hline & $\mathrm{Mn}$ & $8.7 \times 10^{-4}$ & $1.6 \times 10^{-4}$ & & & n.a. & n.a. \\
\hline & $\mathrm{Cu}$ & $2.7 \times 10^{-2}$ & $4.9 \times 10^{-3}$ & & & n.a. & n.a. \\
\hline & $\mathrm{Ni}$ & $1.6 \times 10^{-2}$ & $2.9 \times 10^{-3}$ & & & $4.6 \times 10^{-5}$ & $9.8 \times 10^{-5}$ \\
\hline & $\mathrm{Pb}$ & $5.4 \times 10^{-3}$ & $1.0 \times 10^{-3}$ & & & $5.5 \times 10^{-8}$ & $1.2 \times 10^{-7}$ \\
\hline & $\mathrm{Fe}$ & $5.9 \times 10^{-3}$ & $1.1 \times 10^{-3}$ & & & n.a. & n.a. \\
\hline
\end{tabular}

n.a., not assessed.

\section{Conclusions}

The statistical approach applied in this study can be used for the investigation of the tap water chemical composition, especially in relation to the release of heavy metals. The MANOVA test clearly pointed out that the concentration levels of some heavy metals present in tap water are affected by a series of factors, which therefore must be considered in the water sampling protocol. Disregarding them may lead to erroneous and unreliable water quality analyses and may hinder drawing valid conclusions, at least for the metals considered for MANOVA. In future research, information on the composition of water and the factors that may influence it should be collected with greater care, especially to maintain balanced data for each category (equally sized categories) and thus receive more reliable MANOVA results. The information gathered during the field interview was collected in the extensive database that was used for further statistical calculations on the extraction of factors that can affect favourable enrichment of tap water with significant amounts of trace elements. The results showed a positive correlation between concentrations of heavy 
metals such as $\mathrm{Fe}, \mathrm{Mn}, \mathrm{Zn}, \mathrm{Pb}, \mathrm{Cd}$ and the material of fittings/appliance used as well as with the material of pipe-work. Observed dependencies between the age of connection, age of pipe-work and installation material and concentrations of trace elements found in tap water suggest that additional information about construction properties of the distribution system should be gathered. The knowledge about the discussed parameters can help in the interpretation of results, and as a consequence, it enables the development of optimal methods for decreasing higher concentrations of trace elements in tap water. Although these concentrations are over the maximum permissible levels regarding EU and WHO standards, health-related problems can occur. It is visible in the high value of $\mathrm{HI}$ and $\mathrm{CR}$. The $\mathrm{CR}$ decreases with the following order of the analysed elements $\mathrm{Ni}>\mathrm{Cd}>\mathrm{Cr}>\mathrm{As}=\mathrm{Pb}$. If during sampling the information about necessary factors are collected, the source of higher concentrations of metals and related substances can be more easily found.

Supplementary Materials: The following are available online at https:/ / www.mdpi.com/article/10.3 390/min11111291/s1, Figure S1: Trace elements concentrations in the analysed water by different categories of factors. (a) City: A-Krakow, B-Jaworzno, C-Kamienna Gora, D-Raciborz, EMyszkow. (b) Type of building: A-public building, B-house, C-flat. (c) Age of connection: $A-<10$ years, $B-10-30$ years, $C \longrightarrow 30$ years. (d) Age of tap: $A-<10$ years, $B-10-30$ years, $C-$ $>30$ years. (e) Age of pipe-work: $\mathrm{A}-<10$ years, $\mathrm{B}-10-30$ years, $\mathrm{C} \longrightarrow 30$ years. (f) Stagnation time: $\mathrm{A} \longrightarrow<1 \mathrm{~h}, \mathrm{~B} \longrightarrow>1 \mathrm{~h}$. (g) Material of connection: A-PCV, B-steel, C-galvanised steel, D-stainless steel, E-other. (h) Material of pipe-work: A-PCV, B—steel, C—galvanised steel, D—stainless steel, E-copper, F-other. (i) Material of appliance: A-steel, B-other. (j) Water rating by end-user: A-good, B-unacceptable.

Author Contributions: Conceptualization, K.W., P.R., A.M., E.K., and A.P.; methodology, K.W., P.R., A.M., and E.K.; data analysis, K.W., P.R., and A.M. writing-original draft preparation, K.W. and P.R.; writing-review and editing, K.W., P.R., A.M. and E.K.; supervision, E.K. and A.P. All authors have read and agreed to the published version of the manuscript.

Funding: This research received no external funding.

Institutional Review Board Statement: Not applicable.

Acknowledgments: The paper was prepared as contribution to research no. 16.16.140.315 in the Department of Hydrogeology and Engineering Geology, Faculty of Geology, Geophysics and Environmental Protection, AGH University of Science and Technology.

Conflicts of Interest: The authors declare no conflict of interest.

\section{References}

1. Khan, Z.I.; Ahmad, K.; Rehman, S.; Siddique, S.; Bashir, H.; Zafar, A.; Sohail, M.; Ali, S.A.; Cazzato, E.; De Mastro, G. Health risk assessment of heavy metals in wheat using different water qualities: Implication for human health. Environ. Sci. Pollut. Res. 2017, 24, 947-955. [CrossRef] [PubMed]

2. Krewski, D.; Yokel, R.A.; Nieboer, E.; Borchelt, D.; Cohen, J.; Harry, J.; Kacew, S.; Lindsay, J.; Mahfouz, A.M.; Rondeau, V. Human health risk assessment for aluminium, aluminium oxide, and aluminium hydroxide. J. Toxicol. Environ. Health B 2007, 10, 1-269. [CrossRef]

3. Saha, N.; Rahman, M.S.; Ahmed, M.B.; Zhou, J.L.; Ngo, H.H.; Guo, W. Industrial metal pollution in water and probabilistic assessment of human health risk. J. Environ. Manag. 2017, 185, 70-78. [CrossRef]

4. Amirah, M.N.; Afiza, A.S.; Faizal, W.I.W.; Nurliyana, M.H.; Laili, S. Human health risk assessment of metal contamination through consumption of fish. J. Environ. Pollut. Hum. Health 2013, 1, 1-5. [CrossRef]

5. Giri, S.; Singh, A.K. Human health risk assessment via drinking water pathway due to metal contamination in the groundwater of Subarnarekha River Basin, India. Environ. Monit. Assess. 2015, 187, 63. [CrossRef]

6. Duda, R.; Zdechlik, R.; Kania, J. Semiquantitative Risk Assessment Method for Groundwater Source Protection Using a Processbased Interdisciplinary Approach. Water Resour. Manag. 2021, 35, 3373-3394. [CrossRef]

7. Wongsasuluk, P.; Chotpantarat, S.; Siriwong, W.; Robson, M. Heavy metal contamination and human health risk assessment in drinking water from shallow groundwater wells in an agricultural area in Ubon Ratchathani province, Thailand. Environ. Geochem. Health 2014, 36, 169-182. [CrossRef]

8. Yi, Y.; Yang, Z.; Zhang, S. Ecological risk assessment of heavy metals in sediment and human health risk assessment of heavy metals in fishes in the middle and lower reaches of the Yangtze River basin. Environ. Pollut. 2011, 159, 2575-2585. [CrossRef] 
9. Strzebońska, M.; Gruszecka-Kosowska, A.; Kostka, A. Chemistry and Microbiology of Urban Roof Runoff in Kraków, Poland with Ecological and Health Risk Implications. Appl. Sci. 2020, 10, 8554. [CrossRef]

10. Gruszecka-Kosowska, A. Significance of Environmental Input Data in Risk Assessment Analyses. J. Xenobiot. 2020, 10, 36-38. [CrossRef]

11. Fallahzadeh, R.A.; Ghaneian, M.T.; Miri, M.; Dashti, M.M. Spatial analysis and health risk assessment of heavy metals concentration in drinking water resources. Environ. Sci. Pollut. Res. 2017, 24, 24790-24802. [CrossRef] [PubMed]

12. Mohammadi, A.A.; Zarei, A.; Majidi, S.; Ghaderpoury, A.; Hashempour, Y.; Saghi, M.H.; Alinejad, A.; Yousefi, M.; Hosseingholizadeh, N.; Ghaderpoori, M. Carcinogenic and non-carcinogenic health risk assessment of heavy metals in drinking water of Khorramabad, Iran. MethodsX 2019, 6, 1642-1651. [CrossRef] [PubMed]

13. Mirzabeygi, M.; Abbasnia, A.; Yunesian, M.; Nodehi, R.N.; Yousefi, N.; Hadi, M.; Mahvi, A.H. Heavy metal contamination and health risk assessment in drinking water of Sistan and Baluchistan, Southeastern Iran. Hum. Ecol. Risk Assess 2017, 23, 1893-1905. [CrossRef]

14. Directive. Council Directive 98/83/EC of 3 November 1998 on the Quality of Water Intended for Human Consumption. 1998. Available online: http:/ / data.europa.eu/eli/dir/1998/83/oj (accessed on 8 November 2021).

15. Regulation. Regulation (EC) No 1882/2003 of the European Parliament and of the Council of 29 September 2003 Adapting to Council Decision 1999/468/EC the Provisions Relating to Committees which Assist the Commission in the Exercise of its Implementing Powers Laid Down in Instruments Subject to the Procedure Referred to in Article 251 of the EC Treaty. 2003. Available online: http:/ / data.europa.eu/eli/reg/2003/1882/oj (accessed on 8 November 2021).

16. Regulation. Regulation (EC) No 596/2009 of the European Parliament and of the Council of 18 June 2009 Adapting a Number of Instruments Subject to the Procedure Referred to in Article 251 of the Treaty to Council Decision 1999/468/EC with Regard to the Regulatory Procedure with Scrutiny. Adaptation to the Regulatory Procedure with Scrutiny-Part Four. 2009. Available online: http: / / data.europa.eu/eli/reg/2009/596/oj (accessed on 8 November 2021).

17. Directive. Commission Directive (EU) 2015/1787 of 6 October 2015 Amending Annexes II and III to Council Directive 98/83/EC on the Quality of Water Intended for Human Consumption. 2005. Available online: http:/ / data.europa.eu/eli/dir/2015/1787/oj (accessed on 8 November 2021).

18. RMH. Regulation of the Minister of the Health of 7th December 2017 on the Quality of Water Intended for Human Consumption. J. Law 2017, 2294. Available online: https:/ / oeil.secure.europarl.europa.eu/oeil/popups / ficheprocedure.do?lang=enreference= 2017/0332(COD) (accessed on 8 November 2021).

19. Directive. Directive (EU) 2020/2184 of the European Parliament and of the Council on the Quality of Water Intended for Human Consumption (Recast). 2020. Available online: https:/ / eur-lex.europa.eu/eli/dir/2020/2184/oj (accessed on 21 March 2021).

20. Rusiniak, P.; Wator, K.; Kmiecik, E.; Postawa, A. The influence of selected factors on the concentration of heavy metals in drinking water. In Proceedings of the International Multidisciplinary Scientific GeoConference: Science and Technologies in Geology, Exploration and Mining, Albena, Bulgaria, 29 June-5 July 2017; Volume 17, pp. 921-928.

21. Wator, K.; Kmiecik, E.; Postawa, A. Analysis of factors influencing changes of drinking water chemical composition. Przeglad Geol. 2017, 65, 1388-1392. (In Polish)

22. ISO. ISO 5667-5:2006-Water Quality—Sampling_Part 5: Guidance on Sampling of Drinking Water from Treatment Works and Piped Distribution Systems; International Organization for Standardization: Geneva, Switzerland, 2006.

23. Postawa, A. Best Practice Guide on Sampling and Monitoring of Metals in Drinking Water; IWA Publishing: London, UK, 2012; 156p.

24. Boyd, G.R.; Pierson, G.L.; Kirmeyer, G.J.; Britton, M.D.; English, R.J. Lead release from new end-use plumbing components in Seattle Public Schools. J. Am. Water Work. Ass. 2008, 100, 105-114. [CrossRef]

25. Cartier, C.; Arnold, R.B., Jr.; Triantafyllidou, S.; Prévost, M.; Edwards, M. Effect of flow rate and lead/copper pipe sequence on lead release from service lines. Water Res. 2012, 46, 4142-4152. [CrossRef] [PubMed]

26. Hayes, C. Best Practice Guide on the Control of Lead in Drinking Water; IWA Publishing: London, UK, 2010; 85p.

27. Bhattacharya, P.; Polya, D.; Jovanovic, D. Best Practice Guide on the Control of Arsenic in Drinking Water; IWA Publishing: London, UK, 2017; 300p.

28. Postawa, A.; Hayes, C. Best Practice Guide on the Control of Iron and Manganese in Water Supply; IWA Publishing: London, UK, 2017; 96p.

29. Toczyłowska, B. Wpływ Instalacji Wodociagowych Z Miedzi Na Jakość Wody; Europejski Instytut Miedzi: Wrocław, Poland, 2016; pp. 1-32. (In Polish)

30. Mika, A.; Sekuła, K.; Dendys, M.; Ptaszek, W.; Postawa, A. Drinking of tap water is smart, but how do it better?-A tap water quality research. In Proceedings of the E3S Web of Conferences, Krakow, Poland, 12-13 September 2017; Volume 30, p. 01007. [CrossRef]

31. Postawa, A. The Influence of Sampling Methodology on the Results of Metals Determination in Groundwaters and Drinking Waters. In Water Supply and Water Quality; Dymaczewski, Z., Jeż-Walkowiak, J., Nowak, M., Eds.; Polskie Zrzeszenie Inżynierów i Techników Sanitarnych: Poznań, Poland, 2014; pp. 349-366.

32. Wator, K.; Mika, A.; Postawa, A. Influence of Installation Materials and Water. In Water Supply and Water Quality; Dymaczewski, Z., Jeż-Walkowiak, J., Nowak, M., Eds.; Polskie Zrzeszenie Inżynierów i Techników Sanitarnych: Poznań, Poland, 2016; pp. 877-889. (In Polish) 
33. Dong, W.; Zhang, Y.; Quan, X. Health risk assessment of heavy metals and pesticides: A case study in the main drinking water source in Dalian, China. Chemosphere 2019, 242, 125113. [CrossRef]

34. Hu, G.; Rana, A.; Mian, H.R.; Saleem, S.; Mohseni, M.; Jasim, S.; Hewage, K.; Sadiq, R. Human health risk-based life cycle assessment of drinking water treatment for heavy metal (loids) removal. J. Clean Prod. 2020, 267, 121980. [CrossRef]

35. Hashmi, M.Z.; Yu, C.; Shen, H.; Duan, D.; Shen, C.; Lou, L.; Chen, Y. Concentrations and Human Health Risk Assessment of Selected Heavy Metals in Surface Water of the Siling Reservoir Watershed in Zhejiang Province, China. Pol. J. Environ. Stud. 2014, 23, 801-811.

36. Ukah, B.U.; Egbueri, J.C.; Unigwe, C.O.; Ubido, O.E. Extent of heavy metals pollution and health risk assessment of groundwater in a densely populated industrial area, Lagos, Nigeria. Int. J. Energy Water Res. 2019, 3, 291-303. [CrossRef]

37. Jehan, S.; Khattak, S.A.; Muhammad, S.; Ali, L.; Rashid, A.; Hussain, M.L. Human health risks by potentially toxic metals in drinking water along the Hattar Industrial Estate, Pakistan. Environ. Sci. Pollut. Res. 2020, 27, 2677-2690. [CrossRef] [PubMed]

38. Aithani, D.; Jyethi, D.S.; Siddiqui, Z.; Yadav, A.K.; Khillare, P.S. Source apportionment, pollution assessment, and ecological and human health risk assessment due to trace metals contaminated groundwater along urban river floodplain. Groundw. Sustain. Dev. 2020, 11, 100445. [CrossRef]

39. Bodrud-Doza, M.; Islam, S.D.U.; Rume, T.; Quraishi, S.B.; Rahman, M.S.; Bhuiyan, M.A.H. Groundwater quality and human health risk assessment for safe and sustainable water supply of Dhaka City dwellers in Bangladesh. Groundw. Sustain. Dev. 2020, 10, 100374. [CrossRef]

40. Ji, Y.; Wu, J.; Wang, Y.; Elumalai, V.; Subramani, T. Seasonal variation of drinking water quality and human health risk assessment in Hancheng City of Guanzhong Plain, China. Expos. Health 2020, 12, 469-485. [CrossRef]

41. Janoska, O.; Gruszecka-Kosowska, A. Water quality and human health risk assessment: A case study of the Czarna Przemsza River source in Zawiercie, Poland. Hum. Ecol. Risk Assess. Int. J. 2020, 26, 757-781. [CrossRef]

42. Al-Husseini, A.H.E. Risk assessment of heavy metals in tap drinking water in different age group; in Baghdad city, Iraq. Mesop. Environ. J. 2018, 4, 89-102.

43. Tian, Y.; Li, J.; Jia, S.; Zhao, W. Co-release potential and human health risk of heavy metals from galvanized steel pipe scales under stagnation conditions of drinking water. Chemosphere 2021, 267, 129270. [CrossRef]

44. Singh, K.P.; Malik, A.; Singh, V.K.; Mohan, D.; Sinha, S. Chemometric analysis of groundwater quality data of alluvial aquifer of Gangetic plain, North India. Anal. Chim. Acta 2005, 550, 82-91. [CrossRef]

45. Raju, N.J.; Patel, P.; Gurung, D.; Ram, P.; Gossel, W.; Wycisk, P. Geochemical assessment of groundwater quality in the Dun valley of central Nepal using chemometric method and geochemical modeling. Groundw. Sustain. Dev. 2015, 1, 135-145. [CrossRef]

46. Li, L.; He, Z.; Shields, M.R.; Bianchi, T.S.; Pain, A.; Stoffella, P.J. Partial least squares analysis to describe the interactions between sediment properties and water quality in an agricultural watershed. J. Hydrol. 2018, 566, 386-395. [CrossRef]

47. Singh, K.P.; Malik, A.; Basant, N.; Saxena, P. Multi-way partial least squares modeling of water quality data. Anal. Chim. Acta 2007, 584, 385-396. [CrossRef] [PubMed]

48. Apetrei, C.; Iticescu, C.; Georgescu, L.P. Multisensory System Used for the Analysis of the Water in the Lower Area of River Danube. Nanomaterials 2019, 9, 891. [CrossRef]

49. Siepak, M.; Sojka, M. Application of multivariate statistical approach to identify trace elements sources in surface waters: A case study of Kowalskie and Stare Miasto reservoirs, Poland. Environ. Monit. Assess. 2017, 189, 364. [CrossRef]

50. Singh, K.P.; Malik, A.; Mohan, D.; Sinha, S.; Singh, V.K. Chemometric data analysis of pollutants in wastewater-A case study. Anal. Chim. Acta 2005, 532, 15-25. [CrossRef]

51. Sridharan, M.; Nathan, D.S. Chemometric tool to study the mechanism of arsenic contamination in groundwater of Puducherry region, South East coast of India. Chemosphere 2018, 208, 303-315. [CrossRef] [PubMed]

52. Bucci, A.; Franchino, E.; De Luca, D.A.; Lasagna, M.; Malandrino, M.; Prevot, A.B.; Bianco Prevot, A.; Hernandez Sac, H.O.; Coyoy, I.M.; Sac Escobar, E.O.; et al. Groundwater chemistry characterization using multi-criteria approach: The upper Samalá River basin (SW Guatemala). J. South Am. Earth. Sci. 2017, 78, 150-163. [CrossRef]

53. Yu, Y.; Song, X.; Zhang, Y.; Zheng, F.; Liang, J.; Han, D.; Ma, Y.; Bu, H. Identification of key factors governing chemistry in groundwater near the water course recharged by reclaimed water at Miyun County, Northern China. J. Environ. Sci. 2013, 25, 1754-1763. [CrossRef]

54. Elumalai, V.; Nwabisa, D.P.; Rajmohan, N. Evaluation of high fluoride contaminated fractured rock aquifer in South AfricaGeochemical and chemometric approaches. Chemosphere 2019, 235, 1-11. [CrossRef]

55. Wator, K.; Kmiecik, E.; Lipiec, I. The use of principal component analysis for the assessment of the spatial variability of curative waters from the Busko-Zdrój and Solec-Zdrój region (Poland)-preliminary results. Water Suppl. 2018, 19, 1137-1143. [CrossRef]

56. Rwoo, M.A.; Juahir, H.; Roslan, N.M.; Endut, A.; Kamarudin, M.K.A.; Amran, M.A. Assessment of drinking water quality using principal component analysis and partial least square discriminant analysis: A case study at water treatment plants, Selangor. $J$. Fundam. Appl. Sci. 2017, 9, 157-173. [CrossRef]

57. Garboś, S.; Święcicka, D. Application of bimodal distribution to the detection of changes in uranium concentration in drinking water collected by random daytime sampling method from a large water supply zone. Chemosphere 2015, 138, 377-382. [CrossRef]

58. Hyk, W.; Święcicka, D.; Garboś, S. Application of mixed (bimodal) distribution to human health risk assessment of Cu and Ni in drinking water collected by RDT sampling method from a large water supply zone. Microchem. J. 2013, 110, 465-472. [CrossRef] 
59. Górski, J.; Siepak, M. Metals and related substances in drinking water at consumers in Poznań. Biul. Państwowego Inst. Geol. 2011, 445, 139-148. (In Polish)

60. Górski, J.; Siepak, M. Metals in Drinking Water at Consumers in the Light of Investigations Conducted in the Area of Poznan, Szczecin and Choszczno. In Water Supply and Water Quality; Dymaczewski, Z., Jeż-Walkowiak, J., Eds.; Zrzeszenie Inżynierów i Techników Sanitarnych: Poznań, Poland, 2012; pp. 317-335. (In Polish)

61. Górski, J.; Siepak, M. Assessment of metal concentrations in tap-water-from source to the tap: A case study from Szczecin, Poland. Geologos 2014, 20, 25-33. [CrossRef]

62. Górski, J.; Siepak, M. Metals in Drinking Water at the Consumers Based on the Study Conducted in Selected Cities in Poland. In Oldest Hydrogeologists of the World; Belaruskaya Navuka: Minsk, Belarus, 2016; pp. 155-168.

63. Górski, J.; Siepak, M.; Garboś, S.; Święcicka, D. Preliminary Assessment of Metal Concentrations in Drinking Water in the City of Szczecin (Poland): Human Health Aspects. In Metals and Related Substances in Drinking Water; Hayes, C., Ersoz, M., Barott, L., Postawa, A., Bhattacharya, P., Rosborg, I., Sandhi, A., Joao Benoliel, M., Eds.; IWA Publishing: London, UK, 2012; pp. 91-99.

64. Blazejczyk, K. Natural and Human Environment of Poland. A Geographical Overview. In Climate and Bioclimate of Poland; Institute of Geography and Spatial Organization, Polish Academy of Sciences: Warszawa, Poland, 2006; pp. 31-48.

65. Postawa, A.; Witczak, S. (Eds.) Metals and Related Substances in Drinking Water in Poland; IWA Publishing: London, UK, 2011.

66. Witczak, S.; Szczepański, A.; Mikołajków, J.; Skrzypczyk, L. Protection of groundwater quality and quantity of strategic groundwater resources of the Major Groundwater Basins. Przeglad Geol. 2010, 58, 754-761.

67. ISO. ISO 5667-3:2018 Water Quality—Sampling_Part 3: Preservation and Handling of Water Samples; International Organization for Standardization: Geneva, Switzerland, 2018.

68. ISO. ISO 10523:2008 Water Quality—Determination of pH; International Organization for Standardization: Geneva, Switzerland, 2008.

69. ISO. EN 27888:1993. Water Quality—Determination of Electrical Conductivity; International Organization for Standardization: Geneva, Switzerland, 1993.

70. ISO. ISO 17294-2:2016 Water Quality-Application of Inductively Coupled Plasma Mass Spectrometry (ICP-MS)—Part 2: Determination of Selected Elements Including Uranium Isotopes; International Organization for Standardization: Geneva, Switzerland, 2016.

71. ISO. ISO 11885:2007 Water Quality_Determination of Selected Elements by Inductively Coupled Plasma Optical Emission Spectrometry (ICP-OES); International Organization for Standardization: Geneva, Switzerland, 2007.

72. Tabachnick, B.; Fidell, L.S. Using Multivarite Statistics, 6th ed.; Pearson: Boston, MA, USA, 2012.

73. R Core Team. R: A Language and Environment for Statistical Computing; R Foundation for Statistical Computing: Vienna, Austria, 2020; Available online: https:/ / www.R-project.org/ (accessed on 8 November 2021).

74. Egbueri, J.C.; Mgbenu, C.N. Chemometric analysis for pollution source identification and human health risk assessment of water resources in Ojoto Province, southeast Nigeria. Appl. Water Sci. 2020, 10, 98. [CrossRef]

75. USEPA. Risk Assessment Guidance for Superfund. In Human Health Evaluation Manual (Part A); Office of Emergency and Remedial Respons: Washington, DC, USA, 1989; Volume 1.

76. Egbueri, J.C. Heavy metals pollution source identification and probabilistic health risk assessment of shallow groundwater in Onitsha. Anal. Lett. 2020, 53, 1620-1638. [CrossRef]

77. USEPA. Exposure Factors Handbook; Office of Research and Development, National Center for Environmental Assessment: Washington, DC, USA, 1997.

78. USEPA. Exposure Factors Handbook; (EPA/600/R-09/052F); National Center for Environmental Assessment: Washington, DC, USA, 2011.

79. Bortey-Sam, N.; Nakayama, S.M.; Ikenaka, Y.; Akoto, O.; Baidoo, E.; Mizukawa, H.; Ishizuka, M. Health risk assessment of heavy metals and metalloid in drinking water from communities near gold mines in Tarkwa, Ghana. Environ. Monit. Assess. 2015, 187, 397. [CrossRef]

80. USEPA. Supplemental Guidance for Developing Soil Screening Levels for Superfund Sites; OSWER 9355; Office of Emergency and Remedial Response: Washington, DC, USA, 2002.

81. Hayes, C. Internal Corrosion Control of Water Supply Systems; IWA Publishing: London, UK, 2012; 92p.

82. WHO. Guidelines for Drinking-Water Quality: Fourth Edition Incorporating the First Addendum; World Health Organization: Geneva, Switzerland, 2017.

83. Driscoll, C.T.; Letterman, R.D. Chemistry and fate of Al (III) in treated drinking water. J. Environ. Eng. 1988, 114, 21-37. [CrossRef]

84. Sollars, C.J.; Bragg, S.; Simpson, A.M.; Perry, R. Aluminium in European drinking water. Environ. Technol. 1989, 10, 131-150. [CrossRef]

85. Cui, F.Y. Investigation on aluminum concentration in drinking water in part of China's cities. China Water Wastewater 2002, 18, $5-8$.

86. Alam, I.A.; Sadiq, M. Metal contamination of drinking water from corrosion of distribution pipes. Environ. Pollut. 1989, 57, 167-178. [CrossRef]

87. Gao, J.; Liu, Q.; Song, L.; Shi, B. Risk assessment of heavy metals in pipe scales and loose deposits formed in drinking water distribution systems. Sci. Total Environ. 2019, 652, 1387-1395. [CrossRef]

88. Sarin, P.; Snoeyink, V.L.; Bebee, J.; Jim, K.K.; Beckett, M.A.; Kriven, W.M.; Clement, J.A. Iron release from corroded iron pipes in drinking water distribution systems: Effect of dissolved oxygen. Water Res. 2004, 38, 1259-1269. [CrossRef] 
89. Lytle, D.A.; Schock, M.R. Stagnation Time, Composition, pH, and Orthophosphate Effects on Metal Leaching from Brass; National Risk Management Research Laboratory, Office of Research and Development, US Environmental Protection Agency: Cincinnati, OH, USA, 1996; 184p.

90. Sarver, E.; Zhang, Y.; Edwards, M. Review of brass dezincification corrosion in potable water systems. Corros. Rev. 2010, 28, 155-196. [CrossRef]

91. Kimbrough, D.E. Brass corrosion as a source of lead and copper in traditional and all-plastic distribution systems. J. Am. Water Work. Ass. 2007, 99, 70-76. [CrossRef]

92. Ng, D.Q.; Chen, C.Y.; Lin, Y.P. A new scenario of lead contamination in potable water distribution systems: Galvanic corrosion between lead and stainless steel. Sci. Total Environ. 2018, 637, 1423-1431. [CrossRef]

93. Cartier, C.; Nour, S.; Richer, B.; Deshommes, E.; Prévost, M. Impact of water treatment on the contribution of faucets to dissolved and particulate lead release at the tap. Water Res. 2012, 46, 5205-5216. [CrossRef] [PubMed]

94. Doré, E.; Deshommes, E.; Laroche, L.; Nour, S.; Prévost, M. Lead and copper release from full and partially replaced harvested lead service lines: Impact of stagnation time prior to sampling and water quality. Water Res. 2019, 150, 380-391. [CrossRef]

95. Elfland, C.; Scardina, P.; Edwards, M. Lead-contaminated water from brass plumbing devices in new buildings. J. Am. Water Work. Ass. 2010, 102, 66-76. [CrossRef]

96. Lytle, D.A.; Schock, M.R. Impact of stagnation time on metal dissolution from plumbing materials in drinking water. J. Water Supply Res. 2000, 49, 243-257. [CrossRef]

97. Zlatanović, L.; Van Der Hoek, J.P.; Vreeburg, J.H.G. An experimental study on the influence of water stagnation and temperature change on water quality in a full-scale domestic drinking water system. Water Res. 2017, 123, 761-772. [CrossRef]

98. Sakamoto, A.; Yamasaki, T.; Matsumura, M. Erosion-corrosion tests on copper alloys for water tap use. Wear 1995, 186, 548-554. [CrossRef]

99. Andersen, K.E.; Nielsen, G.D.; Flyvholm, M.A.; Fregert, S.; Gruvberge, B. Nickel in tap water. Contact Dermat. 1983, 9, 140-143. [CrossRef]

100. Gonzalez, S.; Lopez-Roldan, R.; Cortina, J.L. Presence of metals in drinking water distribution networks due to pipe material leaching: A review. Toxicol. Environ. Chem. 2013, 95, 870-889. [CrossRef]

101. McNeill, L.S.; Edwards, M. Iron pipe corrosion in distribution systems. J. Am. Water Work. Ass. 2001, 93, 88-100. [CrossRef]

102. Zietz, B.P.; Richter, K.; Laß, J.; Suchenwirth, R.; Huppmann, R. Release of metals from different sections of domestic drinking water installations. Water Qual. Expo. Health 2015, 7, 193-204. [CrossRef]

103. Zhang, Y.; Griffin, A.; Edwards, M. Effect of Nitrification on Corrosion of Galvanized Iron, Copper, and Concrete. J. Am. Water Work. Ass. 2010, 102, 83-93. [CrossRef]

104. Clark, B.N.; Masters, S.V.; Edwards, M.A. Lead release to drinking water from galvanized steel pipe coatings. Environ. Eng. Sci. 2015, 32, 713-721. [CrossRef] 